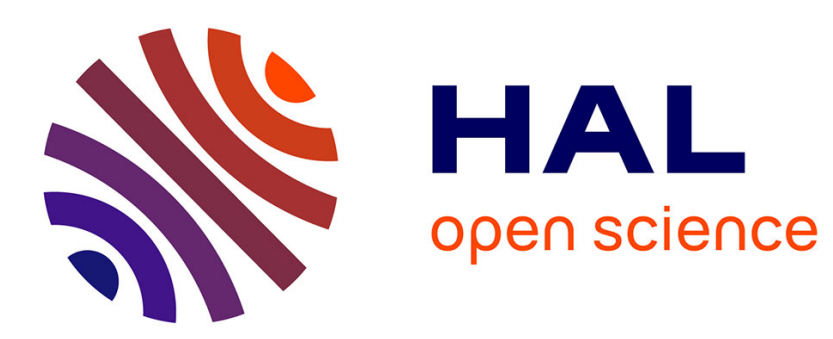

\title{
Trace elements in invertebrates and fish from Kerguelen waters, southern Indian Ocean
}

\author{
Caio C Cipro, Y. Cherel, P. Bocher, F. Caurant, Pierre Miramand, P. \\ Bustamante
}

\section{- To cite this version: \\ Caio C Cipro, Y. Cherel, P. Bocher, F. Caurant, Pierre Miramand, et al.. Trace elements in in- vertebrates and fish from Kerguelen waters, southern Indian Ocean. Polar Biology, 2018, 41 (1), pp.175-191. 10.1007/s00300-017-2180-6 . hal-02338409}

\section{HAL Id: hal-02338409 \\ https://hal.science/hal-02338409}

Submitted on 30 Oct 2019

HAL is a multi-disciplinary open access archive for the deposit and dissemination of scientific research documents, whether they are published or not. The documents may come from teaching and research institutions in France or abroad, or from public or private research centers.
L'archive ouverte pluridisciplinaire HAL, est destinée au dépôt et à la diffusion de documents scientifiques de niveau recherche, publiés ou non, émanant des établissements d'enseignement et de recherche français ou étrangers, des laboratoires publics ou privés. 


\section{Trace elements in invertebrates and fish from Kerguelen waters,} southern Indian Ocean

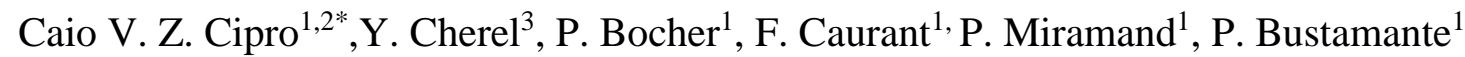

${ }^{1}$ Littoral Environnement et Sociétés (LIENSs), UMR 7266, CNRS-Université de La Rochelle,

2 rue Olympe de Gouges 17042 La Rochelle Cedex 01, France

${ }^{2}$ Laboratório de Química Orgânica Marinha, Instituto Oceanográfico, Universidade de São Paulo, 05508-120 São Paulo, SP, Brazil

${ }^{3}$ Centre d'Etudes Biologiques de Chizé, UMR 7372, CNRS-Université de La Rochelle, BP 14, 79360 Villiers-en-Bois, France

*Corresponding author: Caio V. Z. Cipro e-mail: caiovzc@usp.br 


\section{ABSTRACT:}

Given the lack of background data on essential and non-essential trace elements in invertebrates and fish known to be the predominant prey of marine mammals and seabirds breeding at the Kerguelen Islands, this study intends to provide these results of great influence for predators in higher trophic levels. To this end, plankton organisms ( 9 species/4 phyla), mollusks ( 2 bivalves and 2 squid species) and fishes ( 8 benthic and 10 pelagic species) from Kerguelen waters were analysed for cadmium $(\mathrm{Cd})$, copper $(\mathrm{Cu})$, mercury $(\mathrm{Hg})$, and zinc $(\mathrm{Zn})$. Individual concentrations of non-essential elements (particularly $\mathrm{Cd}$ ) showed larger variation in comparison with essential ones due to homeostasis. Cd ranged over 4 orders of magnitude; however, $\mathrm{Hg}$ ranged only 1, without significant correlation to trophic level. Instead, ecological parameters (benthic/mesopelagic habitat and feeding ecology) showed a more important influence on the results. Concerning seashore organisms, bivalves collected inside the Gulf of Morbihan had higher $\mathrm{Cd}$ concentrations compared to those from the Kerguelen shelf, suggesting a local source of $\mathrm{Cd}$, such as runoff water from bird colonies. Comparison with literature showed metal concentrations in invertebrates and fishes from Kerguelen Islands somewhat lower than in the Antarctic area, with $\mathrm{Hg}$ prevailing in benthic species and $\mathrm{Cd}$ in pelagic ones. In contrast to $\mathrm{Hg}, \mathrm{Cd}$ values of squids, jellyfish and the amphipod Themisto gaudichaudii were significantly higher than all other species. Finally, top predators foraging in this area that can be subject to potentially high $\mathrm{Hg}$ and $\mathrm{Cd}$ exposure through their diet at Kerguelen are reviewed.

Keywords: plankton; myctophid; food web; metals; trace elements; Kerguelen 


\section{INTRODUCTION}

The Southern Ocean constitutes a particular environment for marine biota where human inputs of metals are supposed to be very low. Several essential elements such as iron $(\mathrm{Fe})$ or copper $(\mathrm{Cu})$ are poorly concentrated and/or bioavailable in these waters and could therefore act as limiting factors for phytoplankton (e.g. Coale, 1991). In higher trophic level organisms, low $\mathrm{Cu}$ and zinc $(\mathrm{Zn})$ concentrations in regard to organisms from temperate regions have been found in crustaceans and mollusks (e.g. Bustamante et al. 1998a, 2003; Petri and Zauke 1993; Rainbow 1989), raising the question of how can these organisms cope with essential element supposed deficiency. Several hypotheses have been suggested to answer this question such as a relatively higher efficiency of mechanisms of element uptake compared to similar organisms from nondeficient areas and/or the replacement of essential elements by non-essential ones in biochemical reactions or in enzymes. To date, such replacement has only been evidenced for Zn substitution by Cd in carbonic anhydrase from marine diatoms (Lane and Morel 2000; Lane et al. 2005; Xu et al. 2008). In this context, the interactions between essential and non-essential elements in invertebrates and fish from the Southern Ocean appear poorly documented and, moreover, baseline values necessary for the study of such interactions are even scarcer, if not inexistent in the literature.

Despite the comparatively low inputs of non-essential elements, very high concentrations of $\mathrm{Cd}$ and $\mathrm{Hg}$ have been reported in several organisms from distinct trophic levels in Antarctic and subantarctic environments (Sanchez-Hernandez 2000; Bustamante et al. 2003; Dos Santos et al. 2006; Bargagli 2008). Population growth and industrial development in several countries of the Southern Hemisphere are changing the global pattern of persistent anthropogenic contaminants and new classes of chemicals have already been detected in the Southern Ocean (e.g. Bargagli 2008; Von Waldow 2010; Carravieri et al. 2014a). Very high 
concentrations of both $\mathrm{Cd}$ and $\mathrm{Hg}$ were also found in the tissues of top predators such as seabirds and marine mammals from the Southern Ocean (see the review of Sanchez-Hernandez, 2000). These high trophic level vertebrates are mainly exposed to trace elements through their food (Aguilar et al. 1999; Muirhead and Furness 1988) and some specific prey highly contribute to the exposure to a given element. For example, cephalopod consumption is well-known to provide elevated concentrations of Cd under a bioavailable form (Bustamante et al. 1998b, 2002) and mesopelagic fish contain high amounts of methyl-Hg (e.g. Chouvelon et al. 2012; Monteiro et al. 1996). However, there is only a few data on invertebrates and fish to provide background for explaining the high $\mathrm{Cd}$ and $\mathrm{Hg}$ concentrations in the top predators from the Southern Ocean. Therefore, it is of major concern to provide data about lower trophic level organisms they feed on to give a more comprehensive and evidence supported basis to their contamination pattern. In addition to that, age, trophic position, sex, size among other ecological parameters likely play a role in trace elements concentration in these prey organisms (e.g. Dehn et al 2006; Locarnini and Presley 1995; McIntyre et al. 2007).

Situated near the Polar Front, the Kerguelen Islands are a particularly important area for breeding seabirds and for mammals (see Guinet et al. 1996). Specifically, this archipelago hosts a large and highly diverse avian assemblage (35 different breeding species according to Weimerskirch et al. 1989) and 13 species of marine mammals (3 mysticetes, 7 odontocetes and 3 pinnipeds; Borsa 1997). According to their reproduction strategies, many seabird species catch their prey in the highly productive waters around the Archipelago and feed on a few key species of marine organisms, including some crustaceans (e.g. euphausiids, hyperiids, copepods), fish (e.g. myctophids, notothenioids) and cephalopods (e.g. oceanic squids) (Bocher et al. 2001; Cherel and Hobson 2005; Cherel et al. 2010; Guinet et al. 1996). Their exposure to contaminants and that of their offspring is therefore determined by the concentrations in these 
lower trophic level organisms consumed specifically in this area, at least during the breeding period.

In this context, the present study was conducted to document selected trace element concentrations in zooplankton, mollusks and fishes around the Kerguelen Islands to provide understanding on the degree of metal contamination in low trophic level organisms being the prey of seabirds and marine mammals. To this end, $\mathrm{Cd}, \mathrm{Cu}, \mathrm{Hg}$ and $\mathrm{Zn}$ have been analysed in organisms belonging to different phyla of pelagic invertebrates and in 17 coastal and oceanic fish species to cover the main categories of prey species of the Kerguelen seabird community and of the marine mammals foraging in these waters. The non-essential elements $\mathrm{Cd}$ and $\mathrm{Hg}$ constitute the main metals of concern for wild vertebrates because of their known toxicity (Scheuhammer 1987; Tan et al. 2009; Tartu et al. 2013). In turn, $\mathrm{Cu}$ and $\mathrm{Zn}$ can be disturbed by the interaction of $\mathrm{Cd}$ and $\mathrm{Hg}$ on their regulation proteins such as the metallothioneins (e.g. $\emptyset$ verjordet et al. 2015). The levels of these trace elements were compared within the benthic and pelagic food webs and were globally compared with similar organisms from other marine ecosystems, when available. Finally, the significance of key species in contaminants transfer towards top predators was examined.

\section{MATERIALS AND METHODS}

\section{Sampling of organisms}

Pelagic and benthic organisms were successively collected in the waters surrounding the Kerguelen Island Archipelago (Figure 1) during the austral summers from 1997 to 1999. Information on these organisms are summarised in Table 1. In coastal waters, pelagic zooplankton mainly constituted by hyperiid amphipods (Themisto gaudichaudii) and copepods 
(Paraeuchaeta antarctica), was sampled inside the Morbihan Gulf in March 1997 with an ORInet $\left(2 \mathrm{~m}^{2}, 1 \mathrm{~mm}\right.$ mesh aperture). In this area, several benthic fish species (mostly Notothenidae) were also collected by net fishing overnight (Table 1). Outside the gulf, hyperiid amphipods ( $T$. gaudichaudii), euphausiids (Euphausia vallentini, E. frigida and E. triacantha) and six myctophid species were collected in the eastern part of the peri-insular shelf in February 1998, using a IYGPT trawl (International Young Gadoid Pelagic Trawl; opening: 12 x 7 m) with 10$\mathrm{mm}$ mesh size in the cod-end. Other pelagic material (gelatinous plankton, planktonic crustaceans, squid and fish) were sampled during February 1999 on cruises of the RV "La Curieuse". Benthic fish were collected by bottom trawl used for commercial fishery in the Southern Kerguelen shelf. The samples of the copepod Thysanoessa sp. were obtained from stomach contents of the South Georgian diving petrel collected during investigations on the diet of this species (Bocher et al. 2003) and potential effects of partial digestion must be taken into account.Mussels were collected by hand on the shore during low tides in January 1999. Immediately after collection, the organisms were separated by species, then sex and size or age classes whenever possible (Euphausia vallentini above and below 25mm, and Champsocephalus gunnari adults and juveniles respectively), and frozen in plastic bags or vials. Then, samples were stored at $-20^{\circ} \mathrm{C}$ until analysis. All organisms were analysed whole, except the mussels, which had their shells removed.

\section{Sample preparation and analysis}

Length (mm) and mass (g) of fish and squids were thoroughly determined, as well as the sex, whenever possible (i.e., when size and maturity allowed so), and their gut content was removed. In the case of myctophids, otoliths were taken out to ensure identification of the species. Fish and squids were systematically treated individually, except Harpagifer sp. (12 individuals 
resulted in 4 samples). In contrast, all other invertebrates were pooled, except the jellyfish, which were treated individually. Pooling was primarily made because of analytical reasons, in order to gather enough mass to attend protocol specifications. Sample characteristics, i.e. family, species, length, weight and sex (for squid, fish and some crustacean species), are given in Table 1. Trophic level is assessed based on the personal data of the co-authors, mostly based on stomach contents. Six of the seventeen fish species had also their trophic levels determined by stable isotope ratio of nitrogen published in other studies (Cherel et al. 2010). Since the difference between these two methods was lower than one trophic level, only the former will be further considered during data interpretation.

Samples were dried for two to three days at $50^{\circ} \mathrm{C}$ to a constant weight and then homogenised. Next, 2 aliquots of approx. 100 to $300 \mathrm{mg}$ each (according to availability) of homogenised dry sample were digested with $5 \mathrm{ml}$ of $65 \% \mathrm{HNO}_{3}$ and $0.3 \mathrm{ml}$ of $70 \% \mathrm{HClO}_{4}$ during $72 \mathrm{~h}$ at $80^{\circ} \mathrm{C}$. When the solution was clear, acids were evaporated and the obtained residues were dissolved in $10 \mathrm{ml} 0.3 \mathrm{~N}$ nitric acid. $\mathrm{Cd}, \mathrm{Cu}$ and $\mathrm{Zn}$ were analysed using a flame and graphite furnace atomic absorption spectrophotometer Varian 250 Plus with deuterium background correction. For $\mathrm{Hg}$, aliquots ranging from 5 to $20 \mathrm{mg}$ of dried material were analysed directly in an Advanced Mercury Analyser spectrophotometer (Altec AMA 254). Hg determination involved evaporation of $\mathrm{Hg}$ by progressive heating until $700^{\circ} \mathrm{C}$ were reached and then held under oxygen atmosphere for $3 \mathrm{~min}$, followed by an amalgamation on a gold-net. Afterwards, the net was heated to liberate the collected mercury, subsequently measured by UV atomic absorption spectrophotometry.

Quality assurance was assessed using dogfish liver DOLT-2 (NRCC) and dogfish muscle DORM-2 (NRCC) as reference materials. Such standards were analysed and treated under the same conditions as the samples, with errors in regard to the certified values remaining below $5 \%$ in both cases. Detection limits were 0.004 for $\mathrm{Cd}, 0.5$ for $\mathrm{Cu}, 0.005$ for $\mathrm{Hg}$, and $3 \mu \mathrm{g}$ 
$\mathrm{g}^{-1}$ dry weight (dw) for $\mathrm{Zn}$. All trace element concentrations in Kerguelen Islands marine organisms are reported in $\mu \mathrm{gg}^{-1} \mathrm{dw}$ unless stated otherwise. Water contents allowing recalculations of the metal concentrations from dw to wet weight (ww) are given in Table 1.

\section{Statistical analyses}

Statistical analyses were performed in Microsoft Excel 2007 and Statsoft Statistica 11 and 12. Before analyses, data were checked for normality of distribution and homogeneity of variances using Shapiro-Wilk and Brown-Forsythe tests, respectively, followed by ANOVA and Posthoc Tukey HSD. Spearman's or Pearson's correlations are used to assess the degree of monotonic or linear dependence, respectively, between two variables. At-test was used to assess whether female and male datasets differed when available. All statistically significant results were set at $\alpha=0.05$ and all presented correlations should be assumed significant unless stated otherwise. 


\section{RESULTS}

Metal concentrations in invertebrates and fishes from the Kerguelen Island waters are presented in Table 2. $\mathrm{Cu}, \mathrm{Hg}$, and $\mathrm{Zn}$ concentrations showed, in a general way, a lesser degree of variability when compared to $\mathrm{Cd}$. Indeed, $\mathrm{Cu}, \mathrm{Hg}$ and $\mathrm{Zn}$ average concentrations vary one order of magnitude each whereas $\mathrm{Cd}$ ranged over three orders of magnitude.

Regarding the influence of biological factors in the results, the only crustacean species for which gender comparison was possible was Paraeuchaeta antarctica. All four trace elements presented significant differences between males and females, these later showing significantly higher $\mathrm{Cd}(p<0.001), \mathrm{Cu}(p=0.004)$ and $\mathrm{Zn}(p=0.015)$ levels than males. This difference can be attributed to their considerably higher length and weight (Table 1). Concerning $\mathrm{Hg}$, significantly higher $(p=0.037)$ concentrations were found in males than in females.

In cephalopods, there were no differences on metal concentrations between males and females (for Todarodes angolensis $\mathrm{Cd}, p_{t \text {-test }}=0.149$ and $\mathrm{Hg}, p_{\text {t-test }}=0.867$; for Moroteuthis ingens $\mathrm{Cd}, p_{\text {t-test }}=0.206$ and $\mathrm{Hg}, p_{\text {t-test }}=0.923$ ); moreover, no correlation (neither Pearson's nor Spearman's) between biometrics and metal concentrations were found. In fish, metal concentrations showed no significant difference between the sexes nor correlation with the biometric parameters (total length and total weight) with a few exceptions concerning $\mathrm{Cd}$ and Hg. Cd correlated significantly with total length in L. squamifrons $(r=0.723, p=0.018)$ and with both length and weight in $G$. fraseri ( $r=0.704, p=0.005$ and $0.862, p<0.001$, respectively). Interestingly, a significant negative correlation of $\mathrm{Cd}$ with both biometric parameters was found for juvenile $C$. gunnari $(r=-0.702, p=0.023$ and $-0.636, p=0.048)$ and Protomyctophum tenisoni ( $r=-0.549, p=0.034$ and $-0.627, p=0.012$ ). In turn, $\mathrm{Hg}$ correlated (Spearman's rank) significantly with total length in Gymnoscopelus piabilis $(r=0.591, p=0.033)$ and Lepidonotothen squamifrons ( $r=0.670, p=0.034$ ); with weight in Protomyctophum bolini ( $r=0.697, p=0.004$ ) 
and with both length and weight (shown respectively) in Channichthys rhinoceratus ( $r=0.843$, $p=0.02$ and $r=0.802, p=0.07), G$. fraseri $(r=0.771, p=0.001$ for both), Notothenia rossii ( $r=0.554, p=0.049$ and $r=0.577, p=0.038)$ and Zanclorhynchus spinifer $(r=0.959, p=0.002$ and $r=0.965, p=0.002$ ). Finally, in regard to between-elements relationships, $\mathrm{Cd}$ and $\mathrm{Hg}$ levels correlated with one another significantly in Champsocephalus gunnari (total, $r=0.947$, $p<0.001)$ and $G$. fraseri $(r=0.843, p<0.001)$.

Concerning Bivalves, two mussel species (the blue mussel, Mytilus edulis desolationis and the Magellan mussel, Aulacomya atra) sampled in four different locations: (Foch, Cap Noir, Port-aux-Français and Mayes Island) were analysed in the present study. A significant negative correlation (Spearman's rank) between $\mathrm{Cd}$ and $\mathrm{Cu}(r=-0.725, p=0.039)$ was found in the blue mussel, and also in the Magellan mussel $(r=-0.798, p=0.004)$. This latter species presented yet significant correlation between $\mathrm{Cu}$ and total weight $(r=-0.682, p=0.042), \mathrm{Cd}$ and total weight $(r=0.673, p=0.048)$ and $\mathrm{Cd}$ and $\mathrm{Hg}(r=-0.702, p=0.034)$. When all samples (both species) are considered together, there is a significant correlation between $\mathrm{Cd}$ and total weight $(r=0.547$, $p=0.007)$ and also a significant negative correlation between $\mathrm{Cd}$ and $\mathrm{Cu}(r=-0.537, p=0.009)$.

\section{DISCUSSION}

The main objective of this study was to provide baseline levels in a wide range of phyla which constitute the prey for high trophic level organisms such as large fish, seabirds, and marine mammals. The species collected in the present study represent a wide range of ecological groups from the pelagic/benthic and neritic/oceanic communities from the Kerguelen Island waters. The size of the collected organisms falls within the range of the size preyed by top predators from this area and more specifically, from the large seabird community that includes 35 species (Weimerskirch et al. 1989). 


\section{Influence of biological factors on metal concentrations}

Among factors influencing metal concentrations, sex differences were found for the crustacean Paraeuchaeta antarctica. Higher concentrations of $\mathrm{Cd}, \mathrm{Cu}$ and $\mathrm{Zn}$ in female $P$. antarctica might be due to the fact that metals are highly retained by copepods and $\mathrm{Cd}, \mathrm{Cu}$ and Zn bioaccumulation with the size is likely to have played a major role in this difference, not necessarily via diet, but also possibly via the dissolved phase, in a passive way (Wang et al. 1996; Wang and Fisher 1998) or else via a possible remobilisation due to sexual maturation, as further discussed. In contrast to $\mathrm{Cd}, \mathrm{Cu}$ and $\mathrm{Zn}$, higher $\mathrm{Hg}$ concentrations in males is likely due to the fact that the sampled females could have already reached sexual maturity size and have excreted $\mathrm{Hg}$ in the laid eggs. Indeed, maternal transfer may act as a major pathway for $\mathrm{Hg}(\mathrm{II})$ and MeHg elimination in crustaceans (Tsui and Wang 2004). The size of the specimens analysed here ranged from 5 to $10 \mathrm{~mm}$, whereas this species presents CV (last copepodite stage) at $6.5 \pm 0.3 \mathrm{~mm}$ and CVI (adults) at $8.7 \pm 0.4 \mathrm{~mm}$ (Bocher et al. 2002), therefore the sampleset likely contained sexually mature individuals.

In cephalopods, the lack of difference in $\mathrm{Cd}$ and $\mathrm{Hg}$ concentrations between males and females is surprising considering the sexual dimorphism in both species, females reaching larger sizes than males. Indeed, sexual dimorphism and ontogenic effects can influence in metal concentrations in cephalopods (e.g. Pierce et al., 2008; Chouvelon et al., 2011). The absence of variation of metal concentrations in both cephalopod species is likely due to the limited number of specimens of each sex and limited size range for both T. angolensis and M. ingens. Nevertheless, metal concentrations found in both squid species were among the highest for all the species from the present study, especially for $\mathrm{Cd}$. Cephalopods are considered as superbioaccumulators of many trace elements and their capacity to bioaccumulate remarkable Cd levels was already shown in several environments (Dorneles et al. 2007; Martin and Flegal 1975; Miramand and Bentley 1992; Miramand and Guary 1980), including Kerguelen waters 
(Bustamante et al. 1998b). Even though the specific proteins involved in Cd bioaccumulation are not fully known, its significant correlation (Spearman's rank) with $\mathrm{Zn}(\mathrm{r}=0.902)$ in $T$. angolensis (the highest $\mathrm{Cd}$ level) suggests the involvement of MTLP in Cd detoxification. For $\mathrm{Hg}$ as well, cephalopods were among the most contaminated species. Within this group, $\mathrm{Hg}$ is mainly under the highly bioavailable organic form (Bustamante et al. 2006) and therefore they represent a significant source of this element for their predators.

In fish, the significant negative correlation of $\mathrm{Cd}$ with both biometric parameters (size and weight) for C. gunnari and P. tenisoni could be due to a higher Cd exposure in earlier life stages (due to diet, habitat or maternal transfer), with a growth dilution effect taking place and concentrations decreasing thereafter. Since benthic organisms present, in a general way, overall lower Cd values when compared to pelagic ones (Fig. 2), this is in accordance with previous studies describing C. gunnari as bentho-pelagic, but with a shift from the pelagic to the benthic environment as the fish grow (Kock 2005a, b). Concerning $\mathrm{Hg}$, the correlations found between this element and biometrics are likely related to the bioaccumulation of $\mathrm{Hg}$ as the fish grow. Moreover, benthic species presented mostly higher $\mathrm{Hg}$ levels than pelagic ones (Fig. 2). In sediments, organic carbon and microbial activity play an important role on $\mathrm{Hg}$ bioavailability as microorganisms highly contributes to the methylation of inorganic $\mathrm{Hg}$ (Andersson et al. 1990), enhancing the exposure of benthic species to $\mathrm{Hg}$. In regard to $\mathrm{Cd}$ and $\mathrm{Hg}$ positive significant correlations with size and weight in C. gunnari and G. fraseri, it would mean that these species are simultaneously exposed to sources of both contaminants. This could be due to the consumption 1) of one specific prey that presents high concentrations of $\mathrm{Cd}$ and $\mathrm{Hg}$ or 2) of several prey that present conversely high concentrations of $\mathrm{Cd}$ or $\mathrm{Hg}$. The second hypothesis seem more likely in regard to $C$. gunnari, since its diet in a subantarctic environment (South Georgia Archipelago) comprised a large proportion of Antarctic krill Euphausia superba, knowing that Euphausids had comparatively high $\mathrm{Hg}$ levels (See Table 2) and, more 
importantly, the hyperiid amphipod Themisto gaudichaudii (with very high Cd levels) as the most frequent prey (Kock et al., 1994). In regard to G. fraseri, it feeds mainly on copepods and to a lesser extent, on the Euphausid Thysanoessa spp. (Saunders et al. 2015), both presenting high $\mathrm{Cd}$ and $\mathrm{Hg}$ concentrations (Table 2). Therefore it seems reasonable to state that the first one of the previous hypotheses would be more likely in this case.

The influence of the trophic position on metal concentrations is examined in Figure 2, which presents the concentrations of $\mathrm{Cd}$ and $\mathrm{Hg}$ stratified by trophic level. In this regard, stable isotopes ratios of nitrogen bring slightly superior data for trophic levels (TLs) of six fish species included in the present study (Cherel et al. 2010), all of them inferior to one trophic level: 0.9 TL for Protomyctophum bolini, 0.7 TL for Gymnoscopelus nicholsi, 0.5 TL for P. tenisoni, 0.3 TL for Electrona antarctica and G. fraseri and finally 0.2 TL for G. piabilis. The difference between these TLs obtained by different methods was negligible and did not change the stratification of concentrations along the TLs.

Cd concentrations ranged over 4 orders of magnitude, i.e. from $0.063 \mu \mathrm{g} \mathrm{g}^{-1}$ in Gobionotothen acuta to $79.4 \mu \mathrm{g} \mathrm{g}^{-1}$ in $T$. angolensis across the different trophic levels, interestingly, a relatively similar pattern to the one reported for an Arctic marine food web (Macdonald and Sprague 1988). Moreover, a large intraspecific variation is shown by different taxa as well, such as in salps and specially crustaceans (Table 2). However, no significant correlation between $\mathrm{Cd}$ concentrations and the trophic level of the species was found in our sampling, suggesting that $\mathrm{Cd}$ is not biomagnified within our sampling set. However, it is important to remark that the increase in trophic level within our sample set does not always infer a direct food-consumer link between the sampled organisms, so biomagnification strictu sensu must be regarded with caution. Moreover, samples were taken in different years and interannual and local differences are possible as well. Also, the transfer of Cd appears to be more related to the species rather than to the trophic level itself, as previously shown in other 
environments (Miramand et al. 1999; Pigeot et al. 2006). This specificity is likely related to Cd bioaccumulation capacities which are particularly elevated for some taxa such as the hyperiid amphipods Themisto sp. (e.g., Ritterhoff and Zauke 1997) and cephalopods (e.g., Bustamante et al.1998a, 2002; Dorneles et al. 2007, Penicaud et al. 2017), or particularly weak as in most marine fish species (Kojadinovic et al. 2007; Wang 2002).

The lack of biomagnification is apparently repeated for $\mathrm{Hg}$ in our set of samples, contrary to what is previously reported for local avifauna (Blévin et al. 2013; Carravieri et al. 2014b). It is important to remark that $\mathrm{Hg}$ biomagnification concerns its main organic form, i.e. methyl-Hg, due to its high bioavailability (e.g. Kannan et al. 1998) whereas our analyses were made only for total $\mathrm{Hg}$. A much higher assimilation efficiency is displayed for methyl-Hg than for inorganic $\mathrm{Hg}$ and a slight variation in this property may determine whether or not some of the element is biomagnified (Reinfelder et al. 1998). Yet, the proportion of methyl-Hg is poorly documented for low trophic level prey in the Southern Ocean. This issue clearly deserves further research in this ecologically important and representative oceanographic area.

\section{Sessile organisms as indicators of possible secondary metal sources}

In mussels, the positive correlation between $\mathrm{Cd}$ and weight and the negative correlation between $\mathrm{Cd}$ and $\mathrm{Cu}$ suggest that as they grow, the homeostatically controlled $\mathrm{Cu}$ is proportionally surpassed by the bioaccumulative $\mathrm{Cd}$ in their organisms, likely bound to metallothioneins (Klaassen et al. 1999). Indeed, mussels produce Cd-induced metallothioneins (Mackay et al. 1993) and Cd can displace essential metals such as $\mathrm{Cu}$ and $\mathrm{Zn}$ normally associated to these proteins (Amiard et al. 2006). Tukey post-hoc tests resulted in separated groups for Cd (raw data for average lot length and mass and TE concentrations are available as Online Resource 1). One group containing samples from Foch, Cap Noir and Port-aux-Français; 
and the second one, from Port-aux-Français and Mayes (always in crescent order). This result suggests some local Cd source enrichment inside the Gulf of Morbihan, where Port-auxFrançais, the largest human settlement in the area (between 45 in austral winter and 120 people in austral summer) and Mayes are both located. Conversely, both other locations (Foch and Cap Noir) are exposed to the open ocean, in the northern shore. This is apparently contrary to the $T$. gaudichaudii data (Table 2), which presented levels for continental shelf samples three times higher than coastal ones. However, the average individual weight from the continental shelf samples was around three times the one from coastal samples, therefore there is likely an influence from age and, thus, from bioaccumulation. A strong effect of age is confirmed by a previous study on the closely related species $T$. libellula from the Greenland Sea (Ritterhoff and Zauke 1997). Nevertheless, a growth dilution effect should be expected for the continental shelf samples, which leaves two hypotheses: whether exposure is increased for larger individuals, or the influence of local Cd sources within the Gulf of Morbihan is not as important to T. gaudichaudii as it is for mussels. Since literature presents related species ( $T$. japonica and probably $T$. gaudichaudii as well) switching from herbivory to carnivory during their life cycles (Pakhomov and Perissinotto 1996), the first hypothesis remains more likely, corroborating the existence of a local Cd secondary source.

Using fish for comparison did not prove to be helpful, since the only two species collected inside the Gulf were benthic ( $N$. rossii and P. magellanica) and there was an evident bias in $\mathrm{Cd}$ levels towards pelagic species, as stated above, possibly because of $\mathrm{Cd}$ enriched upwelled waters around the archipelago(Bustamante et al. 1998b, 2003). For coastal sites inside the Morbihan Bay, another source can be suspected. Indeed, Mayes provides diverse and highly suitable breeding sites for large colonies of burrowing petrels, which breed there in very high densities (Weimerskirch et al. 1989), with up to 6 burrows per square metre (Mougeot et al. 1998). Seabird faeces can alter the trace metal composition in soils (Headley 1996) and 
therefore, colonies might work as secondary trace metal sources (see Choy et al. 2010; Espejo et al. 2014). Water percolating bird colonies has already been shown to have an important role in the exposure of terrestrial flora to contaminants in Antarctic lands (Cipro et al. 2011). It is therefore plausible to assume an analogous effect for the mussels when this water reaches the sea. Nevertheless, this subject deserves further investigation.

\section{Comparison with similar ecosystems in other regions}

Table 3 presents a comparison of the obtained results with those from the literature despite the scarcity of data for equivalent organisms in similar environments, which reinforces the need for studies such as this one. Therefore taxonomic, geographic and ecological differences might present some bias that has to be taken into account when interpreting the data.

Having said that, the jellyfish in our work showed Cd values at least one order of magnitude higher than its counterparts from North-eastern Atlantic waters (Caurant et al. 1999). Its $\mathrm{Zn}$ concentrations were around three times higher as well, not characterising the coaccumulation of $\mathrm{Cd}$ and $\mathrm{Zn}$ seen in other cases. To the best of our knowledge, the presence of metallothioneins in jellyfish has not been reported yet.

For Ctenophora, our results are somewhat closer to the ones for the North Atlantic Ocean than the ones for the Mediterranean, suggesting an influence from local conditions. Tunicates presented results for $\mathrm{Cd}$ and $\mathrm{Cu}$ in a reasonable agreement with the ones from the literature.

Crustaceans, in turn, showed some differences: in a general way, Euphausia spp. values of $\mathrm{Cd}, \mathrm{Cu}$ and $\mathrm{Zn}$ are lower than in organisms from Antarctica and Thysanoessa spp. values for Cd were higher than in organisms from the Bering Sea, closer to pollution sources than Kerguelen Islands (Zauke et al. 2003). So, the difference might be due to a species-specific reason or in a lesser extent, to the influence of water masses dynamics 
As for mollusks, bivalves presented lower values when compared to Antarctic filter feeders, even if the previously discussed influence of a local source is considered (Ahn et al. 1996; Bargagli 2001). Cephalopods, on the other hand, presented similar Hg levels when compared to another subantarctic environment, Macquarie Island (McArthur et al. 2003) or slightly superior when compared to branchial hearts concentrations from samples collected off Amsterdam Islands (Kojadinovic et al. 2011), which is located north of the Polar Front. Care must be taken when comparing digestive gland data (Kojadinovic et al. 2011) to muscle or even whole organism data, since this organ might present higher concentrations, even if it does not greatly contribute to the total $\mathrm{Hg}$ burden in some oceanic squids (Bustamante et al. 2006).

For benthic fish species, Antarctic organisms (Table 3) presented levels for both Cd and $\mathrm{Hg}$ one order of magnitude higher than in the present study. For pelagic ones, the only truly pelagic neritic fish present in all sizes throughout the water column is Pleuragramma antarctica (Wöhrmann et al. 1997). For this species, Brasso et al. (2014) present Hg data averaging 0.014 $\mu \mathrm{g} \mathrm{g}^{-1}$ for juveniles and $0.021 \mu \mathrm{g} \mathrm{g}^{-1}$ for adults (for whole fish, after conversion to dry weight). This is an apparent contradiction to the trend previously discussed (Antarctic organisms with higher levels than subantarctic ones), however, this species feeds on a lower trophic level than the ones in Table 3 and also lives in shallower shelf waters (Giraldo et al. 2011; Pinkerton et al. 2013), which makes it less exposed to these contaminants. Nevertheless, Goutte et al. (2015) present an average of $0.065 \mu \mathrm{g} \mathrm{g}^{-1}$ for P. antarcticum collected in Adelie Land, Antarctica, much similar to the concentration we found for E. antarctica.

Taking all the previous information into account, Kerguelen marine invertebrates and fish seemed to present lower metal concentrations when compared to other sub-Antarctic and especially to Antarctic environments, with the exception of some particular species, notably Themisto gaudichaudii (see also Beltcheva et al. 2011; Guynn and Peterson 2008; Hennig et al. 
1985; Kahle and Zauke 2003; McArthur et al. 2003; Rainbow 1989; Stoeppler and Nürnberg 1979 and the comparison in Table 3).

\section{Implications concerning the transfer to predators}

Because all of the species investigated here constitute to a wide extent, primary or secondary prey for seabirds breeding on the Kerguelen Islands, it is important to provide information on their exposure to trace elements. This is especially important for the non-essential $\mathrm{Cd}$ and $\mathrm{Hg}$ which can have toxic effects at different levels on wild vertebrates (e.g. Gallien et al. 2001; Tan et al. 2009; Goutte et al. 2014; Tartu et al. 2013). In addition to linking prey and predator, this section is intended to highlight the fact that some of the accumulation/magnification occur not only in high trophic levels.

In regard to $\mathrm{Cd}$, the main homogenous group after Tukey HSD was composed by all species but T. gaudichaudii, jellyfish and both the cephalopods. T. gaudichaudii is an important part of local macrozooplankton and the main prey for local planktivorous seabirds (Bocher et al. 2001), therefore their main Cd source (Bocher et al. 2003). Jellyfish showed a Cd concentration one to two orders of magnitude higher than the fish, similar to the findings of Caurant et al.(1999). Jellyfish could therefore represent a vector for Cd transfer, since their energetic value is likely very low (Caurant et al. 1999) so their predators should ingest a large amount of them to satisfy their energetic needs. Cephalopods, in turn, may also function as vectors for Cd transfer to top predators (e.g., Bustamante et al. 1998a; Lahaye et al. 2005). This role is even more evident at higher latitudes as they showed somewhat higher $\mathrm{Cd}$ concentrations in Antarctic and subantarctic areas when compared to temperate and tropical waters (e.g. Dorneles et al. 2007; Kojadinovic et al. 2011; Pierce et al. 2008). Since cephalopods are present in the diet of several predators from Kerguelen Islands such as albatrosses or elephant seals (Cherel et al. 2000, 2004; Guinet et al. 1996; Lescroël et al. 2004), their role as Cd vectors is 
evident. Reported concentrations in the kidney of seabirds from other subantarctic areas such as Gough Island in the South Atlantic Ocean clearly highlighted that seabirds feeding on squids displayed higher $\mathrm{Cd}$ concentrations that crustacean- and fish-feeder species (Muirhead and Furness 1988).

$\mathrm{Hg}$, as previously presented, had a much less species-specific distribution, with less interspecific variation when compared to $\mathrm{Cd}$, even though some stratification within the trophic levels could be detected. No statistical difference was found among all invertebrates taken together (Tukey HSD) and, concerning the fish, only Notothenia rossii, Gymnoscopelus piabilis, G. fraseri and C. rhinoceratus (in crescent $\mathrm{Hg}$ concentration) departed from a homogenous group that contained all the other species. The unicorn icefish $C$. rhinoceratus presented elevated $\mathrm{Hg}$ concentrations, which is consistent with its feeding ecology (Kock 2005a,b): indeed, the diet of juveniles is composed by crustaceans and then adults shift to forage on various notothenioids (mostly benthic) and mesopelagic fish in a lesser extent. In turn, mesopelagic fish, notably the myctophids, are among the most $\mathrm{Hg}$ contaminated. Therefore, predators relying on benthic or benthopelagic prey, as the gentoo penguin Pygoscelis papua (Lescroël and Bost 2005) or mesopelagic fish, such as elephant seals Mirounga leonina (Cherel et al. 2008) and the white-chinned petrel Procellaria aequinoctialis (Delord et al. 2010), would be highly exposed to $\mathrm{Hg}$.

The present study highlights that not only top predators will be exposed to elevated amounts of $\mathrm{Cd}$ and $\mathrm{Hg}$ through their diet when consuming specific types of prey, but also lower trophic level organisms can be subject to the same effect. Zooplankton eating predators are exposed to $\mathrm{Cd}$ especially if they consume the amphipod T. gaudichaudii (i.e., Halobaena caerulea, Pachyptila desolata, P. belcheri, Pelecanoides georgicus and P. urinatrix, according to Bocher et al. 2003). Cephalopod eating species as the wandering albatross (Diomedea exulans) and the great-winged-petrel (Pterodroma macroptera) are also highly exposed to Cd 
but also to $\mathrm{Hg}$ which is consistent with the concentrations recorded in their internal tissues and their feathers (Anderson et al. 2009; Bustamante et al. 2016; Muirhead and Furness 1988; Stewart et al. 1999; Tavares et al. 2013) and also with blood (Anderson et al. 2010; Carravieri et al. 2014a). Finally, fish eating species, as the grey (Procellaria cinerea) or the white-chinnedpetrel (Procellaria aequinoctialis) are highly exposed (see Stewart et al. 1999; Anderson et al. 2009; Cipro et al. 2014) to Hg through the consumption of mesopelagic and benthic fish (Delord et al. 2010).

\section{Acknowledgments}

We thank G. Duhamel and the crew of the RV 'La Curieuse' for their help in the collection of the fish specimens. This work was financially supported by the Agence Nationale de la Recherche (program POLARTOP, O. Chastel), the Institut Paul Emile Victor(IPEV, Programme No. 109, H. Weimerskirch), the Terres Australes et Antarctiques Françaises (TAAF) and the CPER (Contrat de Projet Etat-Région) for funding the AMA of the Plateforme Analyses Elémentaires of LIENSs. C.V.Z. Cipro was supported financially through a postdoctoral grant from the University of La Rochelle and the CNRS (French acronym for National Council of Scientific Research), and also scholarships from CAPES (Coordination for the Improvement of Higher Education Personnel via the Science without Borders programme, Brazil) and FAPESP (São Paulo Research Foundation, Brazil) during the course of this work and its publication.

\section{REFERENCES}

Aguilar, A., Borrell, A., Pastor, T., 1999. Biological factors affecting variability of persistent pollutant levels in cetaceans. J. Cetacean Res. Manag. 83-116.

Aguilar A, Borrell A, Pastor T (1999) Biological factors affecting variability of persistent pollutant levels in cetaceans. J Cetacean Res Manag 83-116. 
Ahn I-Y, Lee SH, Kim KT, Shim JH, Kim D-Y (1996) Baseline heavy metal concentrations in the Antarctic clam, Laternula elliptica in Maxwell Bay, King George Island, Antarctica. Mar Pollut Bull 32:592-598. doi: 10.1016/0025-326X(95)00247-K

Amiard J-C, Amiard-Triquet C, Barka S, Pellerin J, Rainbow PS (2006) Metallothioneins in aquatic invertebrates: Their role in metal detoxification and their use as biomarkers. Aquat Toxicol 76:160-202. doi: 10.1016/j.aquatox.2005.08.015

Anderson ORJ, Phillips RA, Mcdonald RA, Shore RF, Mcgill RAR, Bearhop S (2009) Influence of trophic position and foraging range on mercury levels within a seabird community. 375:277-288. doi: 10.3354/meps07784

Anderson ORJ, Phillips RA, Shore RF, McGill RAR, McDonald RA, Bearhop S (2010) Element patterns in albatrosses and petrels: influence of trophic position, foraging range, and prey type. Environ Pollut 158:98-107. doi: 10.1016/j.envpol.2009.07.040

Andersson I, Parkman H, Jernelöv A (1990) The role of sediments as sink or source for environmental contaminants-- a case study of mercury and chlorinated organic compounds. Limnol Jena 20:347-359.

Bargagli R (2008) Environmental contamination in Antarctic ecosystems. Sci Total Environ 400:212-26. doi: 10.1016/j.scitotenv.2008.06.062

Bargagli R (2001) Trace metals in Antarctic organisms and the development of circumpolar biomonitoring networks. Rev Env Contam Toxicol 171:53-110.

Bargagli R, Nelli L, Ancora S, Focardi S (1996) Elevated cadmium accumulation in marine organisms from Terra Nova Bay (Antarctica). Polar Biol 16:513-520. doi: 10.1007/BF02329071

Beltcheva M, Metcheva R, Peneva V, Marinova M, Yankov Y, Chikova V (2011) Heavy metals in Antarctic notothenioid fish from South Bay, Livingston Island, South Shetlands (Antarctica). Biol Trace Elem Res 141:150-158. doi: 10.1007/s12011-0108739-5

Blévin P, Carravieri A, Jaeger A, Chastel O, Bustamante P, Cherel Y (2013) Wide Range of Mercury Contamination in Chicks of Southern Ocean Seabirds. PLoS One 8:e54508. doi: 10.1371/journal.pone.0054508

Bocher P, Caurant F, Miramand P, Cherel Y, Bustamante P (2003) Influence of the diet on the bioaccumulation of heavy metals in zooplankton-eating petrels at Kerguelen archipelago, Southern Indian Ocean. Polar Biol 26:759-767. doi: 10.1007/s00300-003-0552-6

Bocher P, Cherel Y, Alonzo F, Razouls S, Labat JP, Mayzaud P, Jouventin P (2002) Importance of the large copepod Paraeuchaeta antarctica (Giesbrecht, 1902) in coastal waters and the diet of seabirds at Kerguelen, Southern Ocean. J Plankton Res 24:13171333. doi: 10.1093/plankt/24.12.1317 
Bocher P, Cherel Y, Labat J, Mayzaud P, Razouls S, Jouventin P (2001) Amphipod-based food web: Themisto gaudichaudii caught in nets and by seabirds in Kerguelen waters, southern Indian Ocean. Mar Ecol Prog Ser 223:261-276. doi: 10.3354/meps223261

Borsa P (1997) Seasonal trends in the occurrence of marine mammals in the golfe du Morbihan, Kerguelen Islands. Mar Mammal Sci 13:314-316. doi: 10.1111/j.17487692.1997.tb00635.x

Brasso R, Lang J, Jones C, Polito M (2014) Ontogenetic niche expansion influences mercury exposure in the Antarctic silverfish Pleuragramma antarcticum. Mar Ecol Prog Ser 504:253-263. doi: 10.3354/meps10738

Bustamante P, Bocher P, Cherel Y, Miramand P, Caurant F (2003) Distribution of trace elements in the tissues of benthic and pelagic fish from the Kerguelen Islands. Sci Total Environ 313:25-39. doi: 10.1016/S0048-9697(03)00265-1

Bustamante P, Carravieri A, Goutte A, Barbraud C, Delord K, Chastel O, Weimerskirch H, Cherel Y (2016) High feather mercury concentrations in the wandering albatross are related to sex, breeding status and trophic ecology with no demographic consequences. Environ Res 144:1-10. doi: 10.1016/j.envres.2015.10.024

Bustamante P, Caurant F, Fowler SW, Miramand P (1998a) Cephalopods as a vector for the transfer of cadmium to top marine predators in the north-east Atlantic Ocean. Sci Total Environ 220:71-80.

Bustamante P, Cherel Y, Caurant F, Miramand P (1998b) Cadmium, copper and zinc in octopuses from Kerguelen Islands, Southern Indian Ocean. Polar Biol 19:264-271. doi: $10.1007 / \mathrm{s} 003000050244$

Bustamante P, Cosson RP, Gallien I, Caurant F, Miramand P (2002) Cadmium detoxification processes in the digestive gland of cephalopods in relation to accumulated cadmium concentrations. Mar Environ Res 53:227-41.

Bustamante P, Lahaye V, Durnez C, Churlaud C, Caurant F (2006) Total and organic Hg concentrations in cephalopods from the North Eastern Atlantic waters: influence of geographical origin and feeding ecology. Sci Total Environ 368:585-96. doi: 10.1016/j.scitotenv.2006.01.038

Campbell LM, Norstrom RJ, Hobson KA, Muir DCG, Backus S, Fisk AT (2005) Mercury and other trace elements in a pelagic Arctic marine food web (Northwater Polynya, Baffin Bay). Sci Total Environ 351-352:247-263. doi: 10.1016/j.scitotenv.2005.02.043

Carravieri A, Bustamante P, Tartu S, Meillère A, Labadie P, Budzinski H, Peluhet L, Barbraud C, Weimerskirch H, Chastel O, Cherel Y (2014a) Wandering albatrosses document latitudinal variations in the transfer of persistent organic pollutants and mercury to southern ocean predators. Environ Sci Technol 48:14746-14755. doi: $10.1021 / \mathrm{es} 504601 \mathrm{~m}$ 
Carravieri A, Cherel Y, Blévin P, Brault-Fravrou M, Chastel O, Bustamante P (2014b) Mercury exposure in a large subantarctic avian community. Environ Pollut 190C:51-57. doi: 10.1016/j.envpol.2014.03.017

Caurant F, Bustamante P, Bordes M, Miramand P (1999) Bioaccumulation of Cadmium, Copper and Zinc in some Tissues of Three Species of Marine Turtles Stranded Along the French Atlantic Coasts. Mar Pollut Bull 38:1085-1091. doi: 10.1016/S0025326X(99)00109-5

Cherel Y, Ducatez S, Fontaine C, Richard P, Guinet C (2008) Stable isotopes reveal the trophic position and mesopelagic fish diet of female southern elephant seals breeding on the Kerguelen Islands. Mar Ecol Prog Ser 370:239-247. doi: 10.3354/meps07673

Cherel Y, Duhamel G, Gasco N (2004) Cephalopod fauna of subantarctic islands: new information from predators. Mar Ecol Prog Ser 266:143-156. doi: 10.3354/meps266143

Cherel Y, Fontaine C, Richard P, Labat J-P (2010) Isotopic niches and trophic levels of myctophid fishes and their predators in the Southern Ocean. Limnol Oceanogr 55:324332. doi: 10.4319/lo.2010.55.1.0324

Cherel Y, Hobson KA (2005) Stable isotopes, beaks and predators: a new tool to study the trophic ecology of cephalopods, including giant and colossal squids. Proc Biol Sci 272:1601-7. doi: 10.1098/rspb.2005.3115

Cherel Y, Weimerskirch H, Trouvé C (2000) Food and feeding ecology of the neritic-slope forager black-browed albatross and its relationships with commercial fisheries in Kerguelen waters. Mar Ecol Prog Ser 207:183-199. doi: 10.3354/meps207183

Chouvelon T, Spitz J, Caurant F, Mèndez-Fernandez P, Autier J, Lassus-Débat A, Chappuis A, Bustamante P (2012) Enhanced bioaccumulation of mercury in deep-sea fauna from the Bay of Biscay (north-east Atlantic) in relation to trophic positions identified by analysis of carbon and nitrogen stable isotopes. Deep Sea Res Part I Oceanogr Res Pap 65:113-124. doi: 10.1016/j.dsr.2012.02.010

Chouvelon T, Spitz J, Cherel Y, Caurant F, Sirmel R, Mèndez-Fernandez P, Bustamante $\mathrm{P}(2011)$ Inter-specific and ontogenic differences in $\delta 13 \mathrm{C}$ and $\delta 15 \mathrm{~N}$ values and $\mathrm{Hg}$ and Cd concentrations in cephalopods. Mar Ecol Prog Ser 433:107-120. doi: $10.3354 /$ meps09159

Choy ES, Gauthier M, Mallory ML, Smol JP, Douglas MSV, Lean D, Blais JM (2010) An isotopic investigation of mercury accumulation in terrestrial food webs adjacent to an Arctic seabird colony. Sci Total Environ 408:1858-67. doi: 10.1016/j.scitotenv.2010.01.014

Cipro CVZ, Cherel Y, Caurant F, Miramand P, Méndez-Fernandez P, Bustamante P (2014) Trace elements in tissues of white-chinned petrels (Procellaria aequinoctialis) from Kerguelen waters, Southern Indian Ocean. Polar Biol 37:763-771. doi: 10.1007/s00300014-1476-Z 
Cipro CVZ, Yogui GT, Bustamante P, Taniguchi S, Sericano JL, Montone RC (2011) Organic pollutants and their correlation with stable isotopes in vegetation from King George Island, Antarctica. Chemosphere 85:393-8. doi: 10.1016/j.chemosphere.2011.07.047

Coale KH (1991) Effects of iron, manganese, copper, and zinc enrichments on productivity and biomass in the subarctic Pacific. Limnol Oceanogr 36:1851-1864. doi: 10.4319/lo.1991.36.8.1851

Cossa D, Heimbürger L-E, Lannuzel D, Rintoul SR, Butler ECV, Bowie AR, Averty B, Watson RJ, Remenyi T (2011) Mercury in the Southern Ocean. Geochim Cosmochim Acta 75:4037-4052. doi: 10.1016/j.gca.2011.05.001

Dehn L-A, Follmann EH, Thomas DL, Sheffield GG, Rosa C, Duffy LK, O'Hara TM (2006) Trophic relationships in an Arctic food web and implications for trace metal transfer. Sci Total Environ 362:103-23. doi: 10.1016/j.scitotenv.2005.11.012

Delord K, Cotté C, Péron C, MarteauC, Pruvost P, Gasco N, Duhamel G, Cherel Y, Weimerskirch $\mathrm{H}$ (2010) At-sea distribution and diet of an endangered top predator: relationship between white-chinned petrels and commercial longline fisheries. Endanger Species Res 13:1-16. doi: 10.3354/esr00309

Dorneles PR, Lailson-Brito J, Dos Santos RA, da Costa PAS, Malm O, Azevedo AF, Torres JPM (2007) Cephalopods and cetaceans as indicators of offshore bioavailability of cadmium off Central South Brazil Bight. Environ Pollut 148:352-9. doi: 10.1016/j.envpol.2006.09.022

dos Santos IR, Silva-Filho EV, Schaefer C, Sella SM, Silva CA, Gomes V, Passos MJACR, Ngan PV (2006) Baseline mercury and zinc concentrations in terrestrial and coastal organisms of Admiralty Bay, Antarctica. Environ Pollut 140:304-11. doi: 10.1016/j.envpol.2005.07.007

Dubé J (1982) Étude de la distribution de quelques metaux dans le zooplancton de deux ecosystèmes du Saint- Laurent. Université du Québec

Espejo W, Celis JE, González-Acuña D, Jara S, Barra R (2014) Concentration of trace metals in excrements of two species of penguins from different locations of the Antarctic Peninsula. Polar Biol 37:675-683. doi: 10.1007/s00300-014-1468-z

Gallien I, Caurant F, Bordes M, Bustamante P, Miramand P, Fernandez B, Quellard N, Babin $\mathrm{P}(2001)$ Cadmium-containing granules in kidney tissue of the Atlantic white-sided dolphin (Lagenorhyncus acutus) off the Faroe Islands. Comp Biochem Physiol C Toxicol Pharmacol 130:389-95.

Giraldo C, Cherel Y, Vallet C, Mayzaud P, Tavernier E, Moteki M, Hosie G, Koubbi P (2011) Ontogenic changes in the feeding ecology of the early life stages of the Antarctic silverfish (Pleuragramma antarcticum) documented by stable isotopes and diet analysis in the Dumont d'Urville Sea (East Antarctica). Polar Sci 5:252-263. doi: 10.1016/j.polar.2011.04.004 
Goutte A, Bustamante P, Barbraud C, Delord K, Weimerskirch H, Chastel O (2014) Demographic responses to mercury exposure in two closely related Antarctic top predators. Ecology 95:1075-1086. doi: 10.1890/13-1229.1

Goutte A, Cherel Y, Churlaud C, Ponthus J-P, Massé G, Bustamante P (2015) Trace elements in Antarctic fish species and the influence of foraging habitats and dietary habits on mercury levels. Sci Total Environ 538:743-749. doi: 10.1016/j.scitotenv.2015.08.103

Guinet C, Cherel Y, Ridoux V, Jouventin P (1996) Consumption of marine resources by seabirds and seals in Crozet and Kerguelen waters: changes in relation to consumer biomass 1962-85. Antarct Sci 8:23-30.

Guynn KD, Peterson MS (2008) Mercury concentrations in the Patagonian toothfish, Dissostichus eleginoides Smitt 1898, among three distinct stocks. Polar Biol 31:269274. doi: 10.1007/s00300-007-0354-3

Hamanaka T, Tsujita T (1981) Cadmium and zinc concentrations in zooplankton in the subarctic region of the North Pacific. J Oceanogr Soc Japan 37:160-172. doi: 10.1007/BF02309053

Hanchet SM, Tracey D, Dunn A, Horn P, Smith N (2012) Mercury concentrations of two toothfish and three of its prey species from the Pacific sector of the Antarctic. Antarct Sci 24:34-42. doi: 10.1017/S0954102011000654

Headley AD (1996) Heavy metal concentrations in peat profiles from the high Arctic. Sci Total Environ 177:105-111. doi: 10.1016/0048-9697(95)04867-7

Hennig H, Eagle G, McQuaid C, Rickett L (1985) Metal Concentrations in Antarctic Zooplankton Species. In: Siefried W, Condy P, Laws R (eds) Antarctic nutrient cycles and food webs. Springer, Berlin, Heidelberg, New York, pp 656-661

Kahle J, Zauke GP (2003) Trace metals in Antarctic copepods from the Weddell Sea (Antarctica). Chemosphere 51:409-417. doi: 10.1016/S0045-6535(02)00855-X

Kannan K, Smith Jr RG, Lee RF, Windom HL, Heitmuller PT, Macauley JM, Summers JK (1998) Distribution of Total Mercury and Methyl Mercury in Water, Sediment, and Fish from South Florida Estuaries. Arch Environ Contam Toxicol 34:109-118. doi: $10.1007 / \mathrm{s} 002449900294$

Klaassen CD, Liu J, Choudhuri S (1999) Metallothionein: an intracellular protein to protect against cadmium toxicity. Annu Rev Pharmacol Toxicol 39:267-94. doi: 10.1146/annurev.pharmtox.39.1.267

Kock K-H (2005a) Antarctic icefishes (Channichthyidae): a unique family of fishes. A review, Part II. Polar Biol 28:897-909. doi: 10.1007/s00300-005-0020-6

Kock K-H (2005b) Antarctic icefishes (Channichthyidae): a unique family of fishes. A review, Part I. Polar Biol 28:862-895. doi: 10.1007/s00300-005-0019-z 
Kock KH, Wilhelms S, Everson I, Groger J (1994) Variations in the diet composition and feeding intensity of mackerel icefish Champsocephalus gunnari at South Georgia (Antarctic). Mar Ecol Prog Ser 108:43-58. doi: 10.3354/meps 108043

Kojadinovic J, Jackson CH, Cherel Y, Jackson GD, Bustamante P (2011) Multi-elemental concentrations in the tissues of the oceanic squid Todarodes filippovae from Tasmania and the southern Indian Ocean. Ecotoxicol Environ Saf 74:1238-49. doi: 10.1016/j.ecoenv.2011.03.015

Kojadinovic J, Potier M, Le Corre M, Cosson RP, Bustamante P (2007) Bioaccumulation of trace elements in pelagic fish from the Western Indian Ocean. doi: 10.1016/j.envpol.2006.07.015

Lahaye V, Bustamante P, Spitz J, Dabin W, Das K, Pierce GJ, Caurant F (2005) Long-term dietary segregation of common dolphins Delphinus delphis in the Bay of Biscay, determined using cadmium as an ecological tracer. Mar Ecol Prog Ser 305:275-285. doi: 10.3354/meps305275

Lane TW, Morel FM (2000) A biological function for cadmium in marine diatoms. Proc Natl Acad Sci U S A 97:4627-31. doi: 10.1073/pnas.090091397

Lane TW, Saito MA, George GN, Pickering IJ, Prince RC, Morel FMM (2005) A cadmium enzyme from a marine diatom. Nature 434:42. doi: 10.1038/434455a

Lescroël A, Bost CA (2005) Foraging under contrasting oceanographic conditions: the gentoo penguin at Kerguelen Archipelago. Mar Ecol Prog Ser 302:245-261. doi: 10.3354/meps302245

Lescroël A, Ridoux V, Bost CA (2004) Spatial and temporal variation in the diet of the gentoo penguin (Pygoscelis papua) at Kerguelen Islands. Polar Biol 27:206-216. doi: $10.1007 / \mathrm{s} 00300-003-0571-3$

Locarnini S, Presley B (1995) Trace element concentrations in Antarctic krill, Euphausia superba. Polar Biol 15:283-288.

Macdonald C, Sprague J (1988) Cadmium in marine invertebrates and arctic cod in the Canadian Arctic. Distribution and ecological implications. Mar Ecol Prog Ser 47:17-30. doi: $10.3354 /$ meps047017

Mackay EA, Overnell J, Dunbar B, Davidson I, Hunziker PE, Kägi JH, Fothergill JE (1993) Complete amino acid sequences of five dimeric and four monomeric forms of metallothionein from the edible mussel Mytilus edulis. Eur J Biochem 218:183-94.

Martin JH, Flegal AR (1975) High copper concentrations in squid livers in association with elevated levels of silver, cadmium, and zinc. Mar Biol 30:51-55. doi: 10.1007/BF00393752

McArthur T, Butler ECV, Jackson GD (2003) Mercury in the marine food chain in the Southern Ocean at Macquarie Island: an analysis of a top predator, Patagonian toothfish 
(Dissostichus eleginoides) and a mid-trophic species, the warty squid (Moroteuthis ingens). Polar Biol 27:1-5. doi: 10.1007/s00300-003-0560-6

McIntyre JK, Beauchamp DA (2007) Age and trophic position dominate bioaccumulation of mercury and organochlorines in the food web of Lake Washington. Sci Total Environ 372:571-84. doi: 10.1016/j.scitotenv.2006.10.035

Miramand P, Bentley D (1992) Concentration and distribution of heavy metals in tissues of two cephalopods, Eledone cirrhosa and Sepia officinalis, from the French coast of the English Channel. Mar Biol 114:407-414.

Miramand P, Fichet D, Bentley D (1998) Concentrations en métaux lourds (Cd, Cu, Pb, Zn) observées le long du gradient de salinité dans le réseau trophique pélagique de l'estuaire de la Seine. Comptes Rendus l'Académie des Sci Sci la terre des planètes 327:259-264.

Miramand P, Guary JC (1980) High concentrations of some heavy metals in tissues of the mediterranean Octopus. Bull Environ Contam Toxicol 24:738-788.

Miramand P, Guyot T, Rybarczyk H, Elkaim B, Mouny P, Dauvin JC, Bessineton C (2001) Contamination of the biological compartment in the Seine estuary by $\mathrm{Cd}, \mathrm{Cu}, \mathrm{Pb}$, and Zn. Estuaries 24:1056-1065.

Miramand P, Pigeot J, Guyot T, Fichet D (1999) Ecotoxicologie intégrée de l'espèce à l'écosystème. Océanis 25:581-608.

Monteiro LR, Costa V, Furness RW, Santos RS (1996) Mercury concentrations in prey fish indicate enhanced bioaccumulation in mesopelagic environments. Mar Ecol Prog Ser $141: 21-25$.

Mougeot F, Genevois F, Bretagnolle V (1998) Predation on burrowing petrels by the brown skua (Catharacta skua lönnbergi) at Mayes Island, Kerguelen. J Zool London 244:429438. doi: $10.1017 / \mathrm{S} 0952836998003136$

Muirhead SJ, Furness RW (1988) Heavy metal concentrations in the tissues of seabirds from Gough Island, South Atlantic Ocean. Mar Pollut Bull 19:278-283. doi: 10.1016/0025326X(88)90599-1

Øverjordet IB, Kongsrud MB, Gabrielsen GW, Berg T, Ruus A, Evenset A, Borgå K, Christensen G, Jenssen BM (2015) Toxic and essential elements changed in black-legged kittiwakes (Rissa tridactyla) during their stay in an Arctic breeding area. Sci Total Environ 502:548-556. doi: 10.1016/j.scitotenv.2014.09.058

Pakhomov EA, Perissinotto R (1996) Trophodynamics of the hyperiid amphipod Themisto gaudichaudi in the South Georgia region during late austral summer. Mar Ecol Prog Ser 134:91-100. doi: 10.3354/meps134091

Penicaud V, Lacoue-Labarthe T, Bustamante P (2017) Metal bioaccumulation and detoxification processes in cephalopods: a review. Environmental Research, 155: 123133.doi 10.1016/j.envres.2017.02.003 
Petri G, Zauke G-P (1993) Trace metal in the crustaceans in the Antarctic Ocean. Ambio1 22:529-536.

Pierce GJ, Stowasser G, Hastie LC, Bustamante P (2008) Geographic, seasonal and ontogenetic variation in cadmium and mercury concentrations in squid (Cephalopoda: Teuthoidea) from UK waters. Ecotoxicol Environ Saf 70:422-432. doi: 10.1016/j.ecoenv.2007.07.007

Pigeot J, Miramand P, Guyot T, Sauriau P-G, Fichet D, Le Moine O, Huet V (2006) Cadmium pathways in an exploited intertidal ecosystem with chronic cadmium inputs (Marennes-Oléron, Atlantic coast, France). Mar Ecol Prog Ser 307:101-114.

Pinkerton MH, Forman J, Bury SJ, Brown J, Horn P, O'Driscoll RL (2013) Diet and trophic niche of Antarctic silverfish Pleuragramma antarcticum in the Ross Sea, Antarctica. J Fish Biol 82:141-64. doi: 10.1111/j.1095-8649.2012.03476.x

Rainbow P (1989) Copper, cadmium and zinc concentrations in oceanic amphipod and euphausiid crustaceans, as a source of heavy metals to pelagic seabirds. Mar Biol 103:513-518.

Reinfelder JR, Fisher NS, Luoma SN, Nichols JW, Wang WX(1998) Trace element trophic transfer in aquatic organisms: a critique of the kinetic model approach. Sci Total Environ 219:117-35.

Ritterhoff J, Zauke G-P (1997) Influence of body length, life-history status and sex on trace metal concentrations in selected zooplankton collectives from the Greenland Sea. Mar Pollut Bull 34:614-621. doi: 10.1016/S0025-326X(96)00181-6

Romeo M, Gnassia-Barelli M, Carre C (1987) Trace metals: $\mathrm{Cd}, \mathrm{Cu}, \mathrm{Pb}$ and $\mathrm{Zn}$ in gelatinous macroplankton from the Northwestern Mediterranean. Water Res 21:1287-1292.

Romeo M, Gnassia-Barelli M, Carre C (1992) Importance of gelatinous plankton organisms in the storage and transfer of trace metals in the north-western Mediterranean. Mar Ecol Prog Ser 82:267-274.

Sanchez-Hernandez JC (2000) Trace element contamination in Antarctic ecosystems. Rev Env Contam Toxicol 166:83-127.

Saunders RA, Collins MA, Ward P, Stowasser G, ShreeveR, Tarling GA (2015) Distribution, population structure and trophodynamics of Southern Ocean Gymnoscopelus (Myctophidae) in the Scotia Sea. Polar Biol 38:287-308. doi: 10.1007/s00300-014-15849

Scheuhammer AM (1987) The chronic toxicity of aluminium, cadmium, mercury, and lead in birds: a review. Environ Pollut 46:263-95.

Stewart F, Phillips R, Bartle J (1999) Influence of phylogeny, diet, moult schedule and sex on heavy metal concentrations in New Zealand Procellariiformes. Mar Ecol Prog Ser 178:295-305. 
Stoeppler M, Nürnberg HW (1979) Comparative studies on trace metal levels in marine biota. Ecotoxicol Environ Saf 3:335-351. doi: 10.1016/0147-6513(79)90023-X

Tan SW, Meiller JC, Mahaffey KR (2009) The endocrine effects of mercury in humans and wildlife. Crit Rev Toxicol 39:228-269. doi: 10.1080/10408440802233259

Tartu S, Goutte A, Bustamante P, Angelier F, Moe B, Clément-Chastel C, Bech C, Gabrielsen GW, Bustnes JO, Chastel O (2013) To breed or not to breed: endocrine response to mercury contamination by an Arctic seabird. Biol Lett 9:1-4. doi: 10.1098/rsbl.2013.0317

Tavares S, Xavier JC, Phillips RA, Pereira ME, Pardal MA (2013) Influence of age, sex and breeding status on mercury accumulation patterns in the wandering albatross Diomedea exulans. Environ Pollut 181:315-320. doi: 10.1016/j.envpol.2013.06.032

Tsui MTK, Wang WX (2004) Uptake and Elimination Routes of Inorganic Mercury and Methylmercury in Daphnia magna. Environ Sci Technol 38:808-816. doi: $10.1021 / \mathrm{es} 034638 \mathrm{x}$

von Waldow H, Macleod M, Scheringer M, Hungerbühler K (2010) Quantifying remoteness from emission sources of persistent organic pollutants on a global scale. Environ Sci Technol 44:2791-6. doi: 10.1021/es9030694

Wang W (2002) Interactions of trace metals and different marine food chains. Mar Ecol Prog Ser 243:295-309. doi: 10.3354/meps243295

Wang W-X, Reinfelder JR, Lee B-G, Fisher NS (1996) Assimilation and regeneration of trace elements by marine copepods. Limnol Oceanogr 41:70-81. doi:

10.4319/lo.1996.41.1.0070

Wang W, Fisher NS (1998) Accumulation of trace elements in a marine copepod. Limnol Oceanogr 43:273-283. doi: 10.4319/lo.1998.43.2.0273

Weimerskirch H, Zotier R, Jouventin P (1989) The Avifauna of the Kerguelen Islands. Emu 89:15-29.

Wintle NJP, Sleadd IM, Gundersen DT, Kohl K, Buckley BA (2015) Total Mercury in Six Antarctic Notothenioid Fishes. Bull Environ Contam Toxicol 95:557-60. doi: $10.1007 / \mathrm{s} 00128-015-1594-5$

Wöhrmann APA, Hagen W, Kunzmann A (1997) Adaptations of the Antarctic silverfish Pleuragramma antarcticum (Pisces: Nototheniidae) to pelagic life in high-Antarctic waters. Mar Ecol Prog ... 151:205-218.

Xu Y, Feng L, Jeffrey PD, Shi Y, Morel FMM (2008) Structure and metal exchange in the cadmium carbonic anhydrase of marine diatoms. Nature 452:56-61. doi: $10.1038 /$ nature06636 
Zauke G-P, Clason B, Savinov VM, Savinova T (2003) Heavy metals of inshore benthic invertebrates from the Barents Sea. Sci Total Environ 306:99-110. doi: 10.1016/S00489697(02)00487-4 
Caption to figures and table
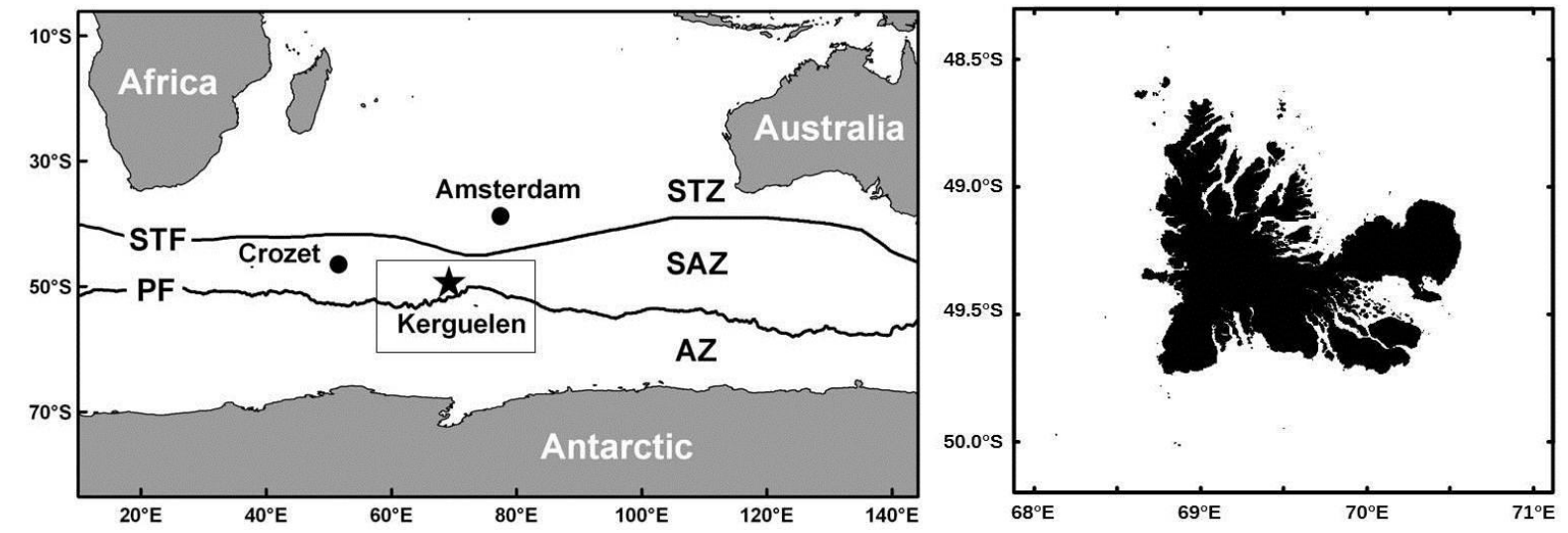

Figure 1 - Kerguelen location in the Southern Indian Ocean among the French Southern Lands (left) and detailed map (right).STZ, SAZ and AZ stand for, respectively, the subtropical, sub-Antarctic and Antarctic zones; whereas STF and PF stand for the subtropical and polar fronts. Taken from Cipro et al (2014). 


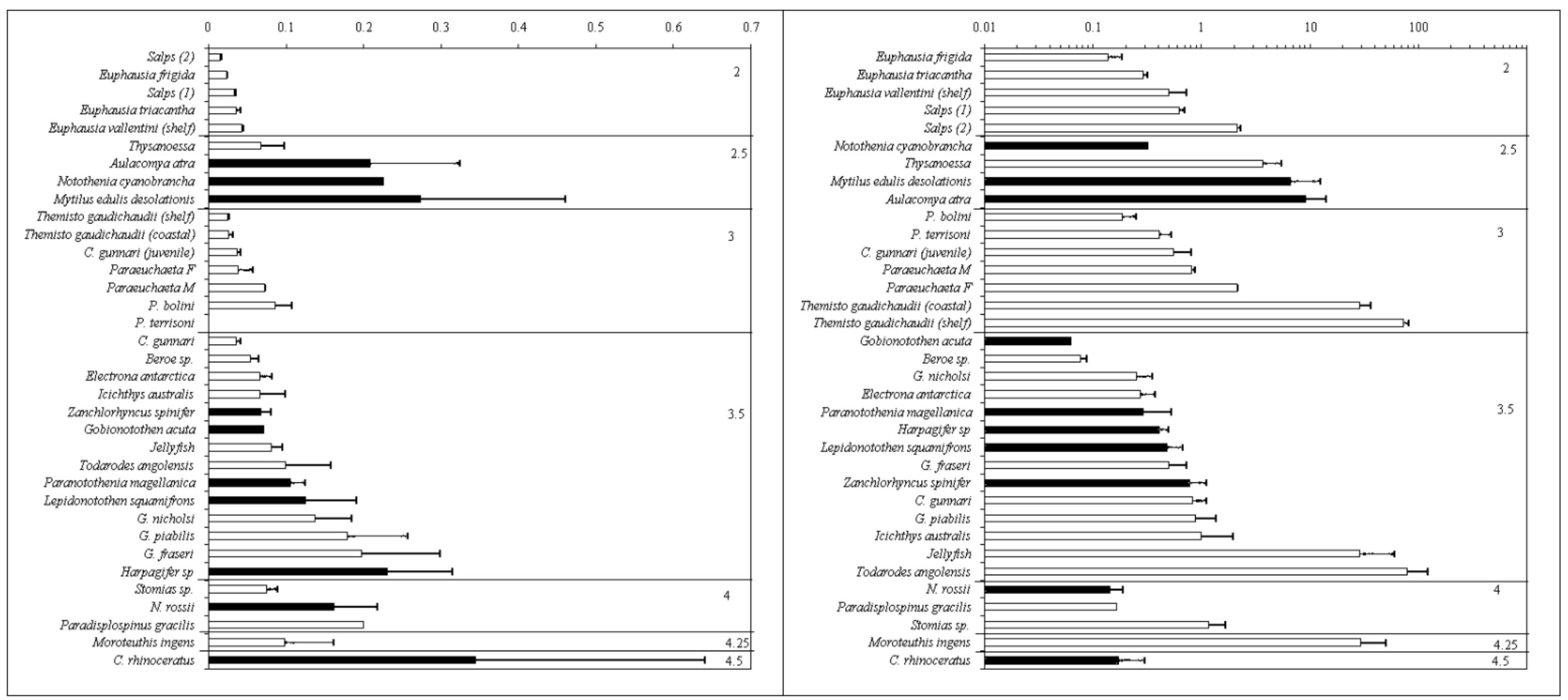

Figure $2-\mathrm{Hg}$ (left, linear scale) and $\mathrm{Cd}$ (right, $\log$ scale) concentrations $\left(\mu \mathrm{g} \mathrm{g}^{-1} \mathrm{dw}\right)$ stratified by trophic level. Benthic species in black, pelagic ones in white. 
Table 1 - Sample characteristics together with water content in the whole organisms (for dry/wet wt metal concentrations conversion). ${ }^{\mathrm{p}}$ : individuals in pooled samples

\begin{tabular}{|c|c|c|c|c|c|c|c|}
\hline $\begin{array}{l}\text { Taxa } \\
\text { Class or family } \\
\text { Species }\end{array}$ & $\begin{array}{l}\text { Sample } \\
\text { Size } \\
(\mathrm{N})\end{array}$ & $\begin{array}{l}\text { Length } \\
(\mathrm{mm})\end{array}$ & $\begin{array}{l}\text { Fresh weight } \\
\quad(\#: \mathrm{g} \text { or } \\
\quad *: \mathrm{mg})\end{array}$ & Sex & $\begin{array}{c}\text { Water content } \\
(\%)\end{array}$ & $\begin{array}{l}\text { Collection } \\
\text { Zone }\end{array}$ & $\begin{array}{c}\text { Functional } \\
\text { Group }\end{array}$ \\
\hline \multicolumn{8}{|l|}{ Cnidarians } \\
\hline Jellyfish & 3 & - & $7-50^{\#}$ & - & $91 \pm 3$ & Shelf waters & Filter-feeder \\
\hline \multicolumn{8}{|l|}{ Ctenophora } \\
\hline Beroe sp. & $15^{\mathrm{p}}$ & - & $1.6-2.3^{\#}$ & - & $92 \pm 1$ & Shelf waters & Filter-feeder \\
\hline \multicolumn{8}{|l|}{ Crustaceans } \\
\hline \multicolumn{8}{|l|}{ Euphausiacea } \\
\hline Euphausia frigida & $90^{\mathrm{p}}$ & $14-18$ & $11-29 *$ & - & $80 \pm 2$ & Eastern Shelf waters & Herbivore \\
\hline E. triacantha & $15^{\mathrm{p}}$ & $27-36$ & $137-410 *$ & - & $70 \pm 3$ & Eastern Shelf waters & Herbivore \\
\hline E. vallentini (small) & $32^{\mathrm{p}}$ & $16-24$ & $19-88 *$ & - & $61 \pm 3$ & Eastern Shelf waters & Herbivore \\
\hline E. vallentini (large) & $60^{p}$ & $25-30$ & $24-96 *$ & - & $73 \pm 3$ & Eastern Shelf waters & Herbivore \\
\hline Thysanoessa sp. & $60^{p}$ & $5-20$ & $1-53 *$ & - & $76 \pm 5$ & Stomach content & Omnivore \\
\hline \multicolumn{8}{|l|}{ Copepoda } \\
\hline Paraeuchaeta antarctica & $60^{p}$ & $5-10$ & $6-18 *$ & q & $64 \pm 2$ & Coastal waters (Morbihan) & Carnivore 1 \\
\hline “ & $125^{\mathrm{p}}$ & $3-5$ & $4-8$ & 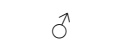 & $69 \pm 1$ & Coastal waters (Morbihan) & Carnivore 1 \\
\hline \multicolumn{8}{|l|}{ Amphipoda } \\
\hline Themisto gaudichaudii & $100^{\mathrm{p}}$ & $14-17$ & $31-51 *$ & - & $71 \pm 2$ & Coastal waters (Morbihan) & Carnivore 1 \\
\hline “ & $32^{\mathrm{p}}$ & $17-27$ & $54-224 *$ & - & $71 \pm 1$ & Eastern Shelf waters & Carnivore 1 \\
\hline \multicolumn{8}{|l|}{ Cephalopods } \\
\hline \multicolumn{8}{|l|}{ Ommastrephidae } \\
\hline Todarodes angolensis & 11 & $197-221$ & $129-214^{\#}$ & $6 \hat{\partial}, 5$ 우 & $77 \pm 3$ & Shelf waters & Carnivore 1-2 \\
\hline \multicolumn{8}{|l|}{ Onychoteuthidae } \\
\hline Moroteuthis ingens & 8 & $103-257$ & $44-472^{\#}$ & $4 \widehat{\jmath}, 4$ ㅇ & $79 \pm 1$ & Shelf waters & Carnivore 1-3 \\
\hline \multicolumn{8}{|l|}{ Bivalvia } \\
\hline \multicolumn{8}{|l|}{ Mytilidae } \\
\hline Mytilus edulis desolationis & $36^{\mathrm{p}}$ & $30-78$ & $1.9-42^{\#}$ & - & $88 \pm 4$ & Cap Noir, Port-aux- & Filter-feeder \\
\hline Aulacomya atra & $27^{p}$ & $38-97$ & $4.8-65^{\#}$ & - & $80 \pm 4$ & Français, Mayes, Foch & Filter-feeder \\
\hline \multicolumn{8}{|l|}{ Tunicates } \\
\hline Salpa thompsoni & $9^{p}$ & $33-42$ & $3.1-5.4^{\#}$ & - & $95 \pm 0$ & Shelf waters & Herbivore \\
\hline “ & $12^{\mathrm{p}}$ & $33-44$ & $3.1-5.9^{\#}$ & - & $94 \pm 2$ & Shelf waters & Herbivore \\
\hline
\end{tabular}


Fishes

Centrolophidae

Icichthys australis

Channichthyidae

Channichthys rhinoceratus

Champsocephalus gunnari (adults)

C. gunnari (juveniles)

Congiopodidae

Zanchlorhyncus spinifer

Gempylidae

Paradiplospinus gracilis

Harpagiferidae

Harpagifer sp.

Myctophidae

$$
\begin{aligned}
& \text { Electrona antarctica } \\
& \text { Gymnoscopelus fraseri } \\
& \text { G. nicholsi } \\
& \text { G. piabilis } \\
& \text { Protomyctophum bolini }
\end{aligned}
$$

P. tenisoni

Notothenidae

Gobionotothen acuta

Lepidonotothen squamifron

Notothenia cyanobranch

N. rossii

Paranotothenia magellanica

Stomidae

Stomias sp.

$257-420$

299-328

$122-154$

126-163

370

$54-75$

48-78

65-82

29-164

$14-162$

49-58

$34-42$

177

234-310

\begin{tabular}{|c|c|}
\hline $125-416^{\#}$ & 5 ๙, 3 + \\
\hline $212-563^{\#}$ & 5 万人, 8 우 \\
\hline $164-232$ \# & $5 \hat{\partial}, 5$ 우 \\
\hline $127-154$ & ND \\
\hline $34-83^{\#}$ & $3 \widehat{\jmath}, 3$ 우 \\
\hline $67^{\#}$ & $0^{\lambda}$ \\
\hline $3.8-9.1^{\#}$ & - \\
\hline $1.3-4.4^{\#}$ & ND \\
\hline $2.5-5.5^{\#}$ & ND \\
\hline $22-42^{\#}$ & 4 우 \\
\hline $17-44^{\#}$ & $5 \hat{\jmath}, 9$ ㅇ \\
\hline $1.2-2.2^{\#}$ & ND \\
\hline
\end{tabular}

195

137-288

147-168

102-178
$177-386^{\#}$

$160^{\#}$

$57-450^{\#}$

74-119 \#

$5 \stackrel{+}{\lambda^{+}, 5}$

ㅇ

5 ๙ิ, 7 ㅇ, $1 \mathrm{ND}$

2 구, 4 우
Shelf waters

Shelf waters (Morbihan)

Shelf waters

Shelf waters

outhern Shelf waters

Oceanic waters

Shelf waters(Morbihan)

Oceanic waters

Oceanic waters

Oceanic waters

Oceanic waters

Oceanic waters

Oceanic waters

Coastal waters (Morbihan)

Shelf waters (Morbihan)

Shelf waters (Morbihan)

Coastal waters (Morbihan)

Shelf waters (Morbihan)

$\begin{array}{lllll}1.1-4.7^{\#} & \text { ND } & 81 \pm 6 & \text { Oceanic waters } & \text { Carnivore } 3\end{array}$

Carnivore 1-2

Carnivore 2-3

Carnivore 1-2

Carnivore 1

Carnivore 1-2

Carnivore 1-3

Carnivore 1-2

Carnivore 1-2

Carnivore 1-2

Carnivore 1-2

Carnivore 1-2

Carnivore 1

Carnivore 1

Carnivore 1-2

Carnivore 1-2

Carnivore 1

Carnivore 2-3

Carnivore 1-2

$\begin{array}{lllll}1.1-4.7^{\#} & \text { ND } & 81 \pm 6 & \text { Oceanic waters } & \text { Carnivore } 3\end{array}$ 
Table 2 - Metal concentrations $\left(\mu \mathrm{gg}^{-1}\right.$ dry wt) of organisms from the Kerguelen Islands. Pooled samples are marked with a ${ }^{p}$

\begin{tabular}{|c|c|c|c|c|c|c|c|c|c|c|}
\hline \multirow{2}{*}{$\begin{array}{l}\text { Group } \\
\quad \text { Species }\end{array}$} & \multirow[b]{2}{*}{ Family } & \multirow[t]{2}{*}{$\mathrm{N}$} & \multicolumn{2}{|c|}{$\mathrm{Cd}$} & \multicolumn{2}{|c|}{$\mathrm{Cu}$} & \multicolumn{2}{|c|}{$\mathrm{Hg}$} & \multicolumn{2}{|c|}{$\mathrm{Zn}$} \\
\hline & & & Mean \pm SD & Range & Mean \pm SD & Range & Mean \pm SD & Range & Mean \pm SD & Range \\
\hline \multicolumn{11}{|l|}{ Ctenophors } \\
\hline Beroe sp. & Beroidae & $3^{\mathrm{p}}$ & $0.077 \pm 0.009$ & $0.070-0.088$ & $6.7 \pm 0.2$ & $6.4-6.9$ & $0.054 \pm 0.010$ & $0.045-0.065$ & $642 \pm 58$ & $582-697$ \\
\hline \multicolumn{11}{|l|}{ Euphausids } \\
\hline Euphausia frigida & Euphausiidae & $4^{\mathrm{p}}$ & $0.137 \pm 0.047$ & $0.109-0.207$ & $5.8 \pm 0.1$ & $5.7-5.8$ & $0.023 \pm 0.002$ & $0.021-0.025$ & $43 \pm 3$ & $41-43$ \\
\hline E. triacantha & $"$ & $3^{p}$ & $0.289 \pm 0.025$ & $0.260-0.306$ & $14.9 \pm 6.7$ & $4.3-19.8$ & $0.036 \pm 0.006$ & $0.029-0.041$ & $55 \pm 2$ & $53-57$ \\
\hline E. vallentini (small) & $"$ & $3^{p}$ & $0.500 \pm 0.217$ & $0.278-0.711$ & $17.8 \pm 2.1$ & $15.4-19.5$ & $0.042 \pm 0.003$ & $0.039-0.045$ & $58 \pm 9$ & $52-68$ \\
\hline E. vallentini (large) & $"$ & $3^{p}$ & $0.659 \pm 0.093$ & $0.589-0.765$ & $30.0 \pm 1.0$ & $29.0-30.9$ & $0.017 \pm 0.001$ & $0.016-0.018$ & $39 \pm 3$ & $37-43$ \\
\hline Thysanoessa sp. & $"$ & $8^{\mathrm{p}}$ & $3.66 \pm 1.80$ & $1.38-6.26$ & $33.7 \pm 12.8$ & $12.8-45.4$ & $0.067 \pm 0.031$ & $0.024-0.125$ & $30 \pm 11$ & $10-47$ \\
\hline \multicolumn{11}{|l|}{ Copepods } \\
\hline Paraeuchaeta antarctica () & Euchaetidae & $3^{p}$ & $2.11 \pm 0.05$ & $2.06-2.16$ & $8.8 \pm 1.1$ & $7.7-9.8$ & $0.038 \pm 0.019$ & $0.023-0.060$ & $245 \pm 66$ & $197-321$ \\
\hline P. $\operatorname{antarctica}(\widehat{)})$ & $"$ & $3^{p}$ & $0.81 \pm 0.05$ & $0.78-0.87$ & $4.9 \pm 0.4$ & $4.4-5.2$ & $0.072 \pm 0.002$ & $0.071-0.074$ & $87 \pm 9$ & $77-92$ \\
\hline \multicolumn{11}{|l|}{ Amphipods } \\
\hline Themisto gaudichaudii(coast) & Hyperridae & $4^{p}$ & $28.5 \pm 7.4$ & $21.2-38.8$ & $12.5 \pm 0.7$ & $11.9-13.4$ & $0.026 \pm 0.005$ & $0.022-0.034$ & $52 \pm 3$ & $48-55$ \\
\hline T. gaudichaudii (shelf) & Hyperridae & $4^{\mathrm{p}}$ & $73.4 \pm 7.2$ & $70.4-81.7$ & $16.0 \pm 7.1$ & $11.8-24.2$ & $0.024 \pm 0.002$ & $0.023-0.027$ & $82 \pm 5$ & $80-88$ \\
\hline \multicolumn{11}{|l|}{ Tunicates } \\
\hline Salpa thompsoni & Salpidae & $3^{p}$ & $0.624 \pm 0.066$ & $0.583-0.700$ & $19.9 \pm 5.5$ & $14.9-25.7$ & $0.033 \pm 0.003$ & $0.030-0.035$ & $969 \pm 142$ & $821-1104$ \\
\hline “ & $"$ & $3^{p}$ & $2.154 \pm 0.135$ & $2.066-2.310$ & $7.7 \pm 1.8$ & $5.6-9.0$ & $0.015 \pm 0.001$ & $0.013-0.016$ & $367 \pm 82$ & $302-458$ \\
\hline \multicolumn{11}{|l|}{ Cnidarians } \\
\hline Jellyfish & Not determined & 3 & $29.0 \pm 30.8$ & $9.98-64.53$ & $7.4 \pm 0.9$ & $6.8-9.4$ & $0.081 \pm 0.015$ & $0.067-0.097$ & $353 \pm 305$ & $142-703$ \\
\hline \multicolumn{11}{|l|}{ Mollusks } \\
\hline Moroteuthis ingens & Onychoteuthidae & 8 & $29.6 \pm 20.0$ & $6.0-60.0$ & $39 \pm 14$ & $23-61$ & $0.099 \pm 0.063$ & $0.034-0.215$ & $66 \pm 20$ & $19-81$ \\
\hline Todarodes angolensis & Ommastrephidae & 11 & $79.4 \pm 41.8$ & $17.5-172.3$ & $80 \pm 39$ & $50-194$ & $0.100 \pm 0.058$ & $0.057-0.270$ & $107 \pm 27$ & $59-158$ \\
\hline Mytilus edulis desolationis & Mytilidae & $12^{\mathrm{p}}$ & $6.50 \pm 5.83$ & $2.27-27.71$ & $6.23 \pm 1.95$ & $3.57-9.08$ & $0.273 \pm 0.187$ & $0.113-0.647$ & $83 \pm 25$ & $48.7-125$ \\
\hline Aulacomya atra & $"$ & $9^{p}$ & $9.11 \pm 4.79$ & $4.05-18.49$ & $8.49 \pm 2.08$ & $5.87-12.71$ & $0.208 \pm 0.116$ & $0.105-0.417$ & $135 \pm 39$ & $84.2-221$ \\
\hline \multicolumn{11}{|l|}{ Benthic fish } \\
\hline Channichthys rhinoceratus & Channichthyidae & 13 & $0.173 \pm 0.125$ & $0.022-0.484$ & $1.8 \pm 0.4$ & $1.3-2.7$ & $0.345 \pm 0.296$ & $0.058-0.870$ & $79 \pm 26$ & $50-128$ \\
\hline Gobiotothen acuta & Notothenidae & 1 & - & 0.063 & - & 2.9 & - & 0.075 & - & 88 \\
\hline Harpagifer sp. & Harpagiferidae & $4^{\mathrm{p}}$ & $0.404 \pm 0.091$ & $0.330-0.536$ & $3.5 \pm 0.45$ & $3.00-3.93$ & $0.230 \pm 0.084$ & $0.128-0.334$ & $107 \pm 19$ & $80-123$ \\
\hline Lepidonotothen squamifrons & Notothenidae & 10 & $0.475 \pm 0.198$ & $0.232-0.808$ & $1.5 \pm 0.4$ & $1.1-2.5$ & $0.150 \pm 0.089$ & $0.063-0.271$ & $43 \pm 9$ & $31-58$ \\
\hline Notothenia cyanobrancha & $"$ & 1 & - & 0.323 & - & 2.1 & - & 0.216 & - & 64 \\
\hline
\end{tabular}




\begin{tabular}{|c|c|c|c|c|c|c|c|c|c|c|}
\hline N. rossii & $"$ & 13 & $0.134 \pm 0.043$ & $0.084-0.229$ & $3.0 \pm 1.0$ & $1.6-4.9$ & $0.145 \pm 0.053$ & $0.072-0.260$ & $47 \pm 9$ & $27-58$ \\
\hline Paranotothenia magellanica & $"$ & 6 & $0.288 \pm 0.234$ & $0.095-0.650$ & $2.2 \pm 0.2$ & $1.9-2.6$ & $0.106 \pm 0.019$ & $0.075-0.126$ & $57 \pm 4$ & $53-64$ \\
\hline Zanclorhyncus spinifer & Congiopodidae & 6 & $0.781 \pm 0.320$ & $0.322-1.173$ & $1.8 \pm 0.2$ & $1.5-2.1$ & $0.067 \pm 0.013$ & $0.054-0.083$ & $40 \pm 6$ & $35-52$ \\
\hline \multicolumn{11}{|l|}{ Pelagic fish } \\
\hline Champsocephalus gunnari & Channichthyidae & 10 & $0.835 \pm 0.267$ & $0.412-1.323$ & $1.6 \pm 0.4$ & $0.8-2.1$ & $0.036 \pm 0.006$ & $0.028-0.049$ & $67 \pm 7$ & $58-82$ \\
\hline C. gunnari (juveniles) & $"$ & 10 & $0.556 \pm 0.248$ & $0.355-1.176$ & $2.4 \pm 0.8$ & $2.0-4.6$ & $0.036 \pm 0.005$ & $0.026-0.041$ & $81 \pm 8$ & 73-91 \\
\hline Electrona antarctica & Myctophidae & 15 & $0.270 \pm 0.101$ & $0.132-0.506$ & $2.1 \pm 0.5$ & $1.6-3.5$ & $0.066 \pm 0.015$ & $0.046-0.100$ & $22 \pm 3$ & $17-28$ \\
\hline Gymnoscopelus fraseri & $"$ & 15 & $0.496 \pm 0.233$ & $0.256-0.929$ & $3.2 \pm 0.6$ & $2.4-4.8$ & $0.197-0.101$ & $0.094-0.424$ & $27 \pm 2$ & 24-31 \\
\hline G. nicholsi & $"$ & 4 & $0.251 \pm 0.098$ & $0.180-0.392$ & $2.2 \pm 0.7$ & $1.4-2.9$ & $0.137 \pm 0.047$ & $0.096-0.200$ & $19 \pm 1$ & $17-20$ \\
\hline G. piabilis & $"$ & 14 & $0.887 \pm 0.454$ & $0.453-1.826$ & $2.3 \pm 0.3$ & $1.6-2.9$ & $0.179 \pm 0.078$ & $0.067-0.333$ & $28 \pm 4$ & $20-35$ \\
\hline Icichthys australis & Centrolophidae & 8 & $0.903 \pm 0.755$ & $0.143-2.320$ & $1.2 \pm 0.2$ & $0.6-1.5$ & $0.064 \pm 0.026$ & $0.041-0.112$ & $26 \pm 5$ & $15-31$ \\
\hline Paradiplospinus gracilis & Gempylidae & 1 & - & 0.164 & - & 1.4 & - & 0.200 & - & 26 \\
\hline Protomyctophum bolini & Myctophidae & 15 & $0.188 \pm 0.063$ & $0.105-0.341$ & $2.7 \pm 0.4$ & $2.0-3.4$ & $0.086 \pm 0.022$ & $0.059-0.135$ & $32 \pm 5$ & $25-43$ \\
\hline P. tenisoni & $"$ & 15 & $0.408 \pm 0.112$ & $0.289-0.744$ & $3.6 \pm 0.5$ & $3.0-4.6$ & NA & NA & $44 \pm 5$ & $38-56$ \\
\hline Stomias sp. & Stomidae & 14 & $1.168 \pm 0.470$ & $0.423-2.359$ & $3.9 \pm 1.5$ & $2.2-8.0$ & $0.075 \pm 0.014$ & $0.053-0.098$ & $54 \pm 13$ & $39-83$ \\
\hline
\end{tabular}




\begin{tabular}{|c|c|c|c|c|c|c|}
\hline $\begin{array}{l}\text { Taxa } \\
\quad \text { Species }\end{array}$ & Location & $\mathrm{Cd}$ & $\mathrm{Cu}$ & $\mathrm{Hg}$ & $\mathrm{Zn}$ & Reference \\
\hline \multicolumn{7}{|l|}{ Cnidarians } \\
\hline Unidentified jellyfish & Southern Indian Ocean & $29.0 \pm 30.8$ & $7.4 \pm 0.9$ & $0.081 \pm 0.015$ & $353 \pm 305$ & Present study \\
\hline Pelagia noctiluca & Mediterranean Sea & 0.4 & 2.0 & - & 46 & Romeo et al. (1987) \\
\hline Velella velella & Mediterranean Sea & $1.2 \pm 0.5$ & $5.7 \pm 0.7$ & - & $118 \pm 34$ & $"$ \\
\hline “ & Mediterranean Sea & $2.7 \pm 0.9$ & $9.3 \pm 1.9$ & - & $100 \pm 18$ & $"$ \\
\hline Sagartia troglodytes & Seine estuary, France & 0.06 & 5.8 & - & 238 & Miramand et al. (2001) \\
\hline \multicolumn{7}{|l|}{ Ctenophora } \\
\hline Beroe sp. & Southern Indian Ocean & $0.077 \pm 0.009$ & $6.7 \pm 0.2$ & $0.054 \pm 0.010$ & $642 \pm 58$ & Present study \\
\hline Beroe ovate & Mediterranean Sea & $1.4 \pm 0.4$ & $2.8 \pm 0.8$ & - & $29 \pm 9$ & Romeo et al. (1992) \\
\hline “ & North Atlantic & 0.16 & 2.0 & - & 52 & Dubé (1982) \\
\hline \multicolumn{7}{|l|}{ Tunicates } \\
\hline Salpa thompsoni & Southern Indian Ocean & $0.624 \pm 0.066$ & $19.9 \pm 5.5$ & $0.033 \pm 0.003$ & $969 \pm 142$ & Present study \\
\hline “ & Southern Indian Ocean & $2.154 \pm 0.135$ & $7.7 \pm 1.8$ & $0.015 \pm 0.001$ & $367 \pm 82$ & Present study \\
\hline S. maxima & Mediterranean Sea & $0.4 \pm 0.4$ & $5.9 \pm 2.4$ & - & $79 \pm 20$ & Romeo et al. (1992) \\
\hline S. fusiformis & Mediterranean Sea & $1.1 \pm 1.0$ & $6.6 \pm 4.9$ & - & $64 \pm 28$ & $"$ \\
\hline \multicolumn{7}{|l|}{ Euphausiacea } \\
\hline Euphausia frigida & Southern Indian Ocean & $0.109-0.207$ & $5.7-5.8$ & $0.021-0.025$ & $41-43$ & Present study \\
\hline E. triacantha & Southern Indian Ocean & $0.260-0.306$ & $4.3-19.8$ & $0.029-0.041$ & $53-57$ & Present study \\
\hline “ & Southern Ocean & 9.0 & 31 & - & 402 & Hennig et al., (1985) \\
\hline E. superba & Western Antarctic Peninsula & $0.13-0.75$ & $37.8-140$ & $0.0131-0.0489$ & $35.2-51.3$ & Locarnini and Presley (1995) \\
\hline E. vallentini & Southern Indian Ocean & $0.278-0.765$ & $15.4-30.9$ & $0.016-0.045$ & $37-68$ & Present study \\
\hline Thysanoessa longipes & Bering Sea & $0.36-1.14$ & - & - & $59-88$ & Hamanaka and Tsujita (1981) \\
\hline Thysanoessa sp. & Southern Indian Ocean & $1.38-6.26$ & $12.8-45.4$ & $0.024-0.125$ & $10-47$ & Present study \\
\hline \multicolumn{7}{|l|}{ Copepoda } \\
\hline Paraeuchaeta antarctica & Southern Indian Ocean & $0.78-2.16$ & 4.4-9.8 & $0.023-0.074$ & $77-321$ & Present study \\
\hline Calanus hyperboreus & Baffin Bay, Canadian Arctic & $1.62 \pm 0.79$ & $1.55 \pm 0.57$ & $0.025 \pm 0.017$ & $17.73 \pm 0.65$ & Campbell et al. (2005) \\
\hline \multirow{2}{*}{ Several species } & Fram strait, Arctic & $0.32-0.75$ & $4.0-7.5$ & $0.31-0.68$ & $79-351$ & \multirow[t]{2}{*}{ Ritterhoff and Zauke (1997) } \\
\hline & Greenland Sea & $0.12-0.69$ & $3.8-5.9$ & $0.2-0.5$ & $86-389$ & \\
\hline \multirow{2}{*}{$\begin{array}{l}\text { Pooled (Eurytemora affinis, Acartia } \\
\text { clausi and Temora longicornis) }\end{array}$} & Seine estuary, high salinity & $0.9 \pm 0.4$ & $15 \pm 6$ & - & $260 \pm 68$ & \multirow{2}{*}{ Miramand et al. (1998) } \\
\hline & Seine estuary, low salinity & $5.5 \pm 2.1$ & $47 \pm 27$ & - & $480 \pm 190$ & \\
\hline Several species & Weddel Sea, Antarctica & $2.3-14.4$ & - & - & - & (Kahle and Zauke, 2003) \\
\hline
\end{tabular}




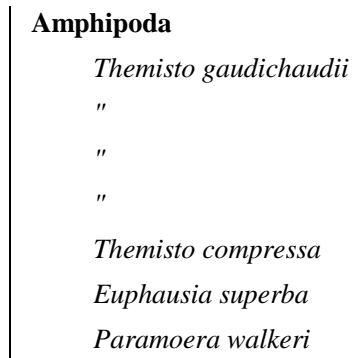

\section{Bivalvia}

Adamussium colbecki (digestive gland)

Laternula elliptica(digestive gland)

Mytilus edulis desolationis

Aulacomya atra

Cephalopods

Moroteuthis ingens

Todarodes angolensi

Todarodes fillipovae (branchial heart)

Todarodes fillipovae (digestive gland)

\section{Benthic fish}
Notothenia rossii
N. coriiceps (body)
$N$. coriiceps (muscle)
$N$. coriiceps (liver)
Notothenia spp.

Trematomus newnesi

Trematomus newnesi (kidney)

T. bernachii

\section{Pelagic fish}

Electrona antarctica

Dissostichus eleginoides

$"$
21.2-81.7

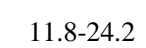

\section{$34 \pm 26$}

$\sim 45 / 55^{\circ} \mathrm{S} 170^{\circ} \mathrm{E}$ ( $\mathrm{N}$ of the Front)

$$
\text { Antarctica }
$$

Northeastern Atlantic

$$
\text { Antarctica }
$$

Terra Nova Bay, Antarctica

Terra Nova Bay, Antarctica

Maxwell Bay, Antarctica

Southern Indian Ocean

Southern Indian Ocean

Southern Indian Ocean

Macquarie Island

Southern Indian Ocean

Southern Indian Ocean

Southern Indian Ocean

Livingston Island, Antarctica Adelie Land, Antarctica

$$
\text { " }
$$

Admiralty Bay, Antarctica

$$
"
$$

Terra Nova Bay, Antarctica

McMurdo Sound, Antarctica

$$
\begin{gathered}
\text { Southern Indian Ocean } \\
\text { Scotia Sea, Antarctica } \\
\text { South Georgia } \\
\text { Prince Edwards Islands } \\
\text { Chilean ZEE around } 40^{\circ} \mathrm{S}
\end{gathered}
$$

$38 \pm 24$

$118 \pm 81$

10.8-117

35.5-108

0.15-1.5

5.1-10.9

$11.2-79.3$

18.6-66.7

30.0-85.5

$55.7 \pm 27$

$11.5 \pm 4.1$

$6.50 \pm 5.83$

$9.11 \pm 4.79$

$38.1+5.0$

$38.1 \pm 5.0$

$8.49 \pm 2.08$

$29.6 \pm 20.0$

$39 \pm 14$

$79.4 \pm 41.8$

$34.3 \pm 19.7$

$246 \pm 187$

$80 \pm 39$

$179 \pm 87.5$

$218 \pm 196$

$0.134 \pm 0.043$

$3.0 \pm 1.0$

$0.28 \pm 0.02$

$1.64 \pm 1.78$

$9.032 \pm 3.215$

$11.8 \pm 4.1$

$-$

$1.86 \pm 0.89$

-

$0.270 \pm 0.101$

0.003

$2.1 \pm 0.5$

0.17
0.005

$0.23 \pm 0.01$

$0.8 \pm 0.07$

$0.73 \pm 0.10$

48-88

$529 \pm 238$

$587 \pm 560$

44.6-82.6

58.5-109

$42.0-74.8$

$-$

$0.35 \pm 0.08$

$0.273 \pm 0.187$

$0.208 \pm 0.116$

$0.099 \pm 0.063$

$0.086 \pm 0.017$

$0.42 \pm 0.17$

$0.14 \pm 0.06$

$0.145 \pm 0.053$

$0.221 \pm 0.085$

0.0163

0.016

$0539 \pm 0.0321$

$153 \pm 39$

$83 \pm 25$

$135 \pm 39$

$66 \pm 20$

$107 \pm 27$

$65.6 \pm 15.0$

$94.3 \pm 66.1$

$47 \pm 9$

$93.05 \pm 2.15$

$119 \pm 17$

64.6

99.1

-

$22 \pm 3$

-

$-$

-
Present study

Hennig et al. (1985)

Rainbow (1989)

Bargagli et al. (1996)

Bargagli (2001)

Ahn et al. (1996)

Present study

Present study

Present study

McArthur et al. (2003)

Present study

Kojadinovic et al.(2011)

Present study

Beltcheva et al. (2011)

Goutte et al., (2015)

dos Santos et al. (2006)

$$
"
$$

Bargagli et al. (1996)

Wintle et al. (2015)

Present study

Stoeppler and Brandt (1979)

Guynn and Peterson (2008) 
Macquarie Island Southern Ocean (Pacific sector)

Dissostichus mawson

Antimora rostrata

Macrourus whitsoni

Pleuragramma antarcticum

P. antarcticum (adult)

P. antarcticum (juvenile)

délie Land, Antarctica

Ross Sea shelf, Antarctica

Ross Sea shelf, Antarctica
$0.33+0.12$

$0.43(0.15-0.97)$

$0.16(0.02-0.70)$

$0.19(0.04-0.68)$

$0.38(0.01-1.10)$

$0.065 \pm 0.009$

$0.021 \pm 0.009$

$0.014 \pm 0.004$
McArthur et al. (2003)

Hanchet et al. (2012)
Goutte et al.(2015)

Brasso et al.(2014) 